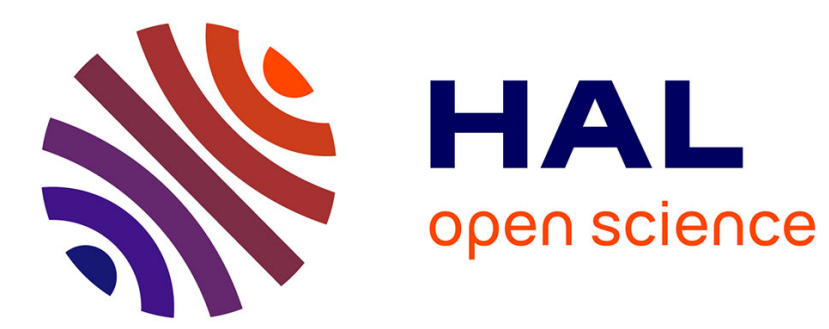

\title{
Determinants of Mobile Broadband Use in Developing Economies: Evidence from Sub-Saharan Africa
}

\author{
Maude Hasbi, Antoine Dubus
}

\section{To cite this version:}

Maude Hasbi, Antoine Dubus. Determinants of Mobile Broadband Use in Developing Economies:

Evidence from Sub-Saharan Africa. 2019. hal-02264651

\section{HAL Id: hal-02264651 \\ https://hal.science/hal-02264651}

Preprint submitted on 7 Aug 2019

HAL is a multi-disciplinary open access archive for the deposit and dissemination of scientific research documents, whether they are published or not. The documents may come from teaching and research institutions in France or abroad, or from public or private research centers.
L'archive ouverte pluridisciplinaire HAL, est destinée au dépôt et à la diffusion de documents scientifiques de niveau recherche, publiés ou non, émanant des établissements d'enseignement et de recherche français ou étrangers, des laboratoires publics ou privés. 


\title{
Determinants of Mobile Broadband Use in Developing Economies: Evidence from Sub-Saharan Africa
}

\author{
Maude Hasbi* $\quad$ Antoine Dubus ${ }^{\dagger}$
}

August 7, 2019

\begin{abstract}
Broadband is seen as a vector of economic growth and social development. In the developing world, mobile technologies are widely adopted and mobile broadband is progressively rolled-out with high expectations on its impact on the countries' development. We highlight what the determinants of mobile broadband use are in four Sub-Saharan countries. Using micro-level data coming from household surveys over 5 years, from 2013 to 2017, we show that SIM card ownership and being part of an online social community has a strong positive impact on mobile broadband use. We also highlight a positive correlation between digital inclusion and financial inclusion as mobile money users and bank account users are found to be more inclined to use mobile broadband. However, beyond apparent similarities, mobile broadband is used in different ways according to countries specificities. For instance, among the non-mobile owners in Nigeria, the unemployed are the most likely to use mobile broadband, most probably for job search practices, while it is rather used by students for information gathering in other countries. Finally we show that those excluded from mobile broadband use are the eldest, those with the lowest level of education, and women.
\end{abstract}

Key Words: Mobile Broadband Use; Developing Economy; Financial Inclusion; Digital Gap.

JEL Classification: I30, O12, L50, L96, O55.

${ }^{*}$ Chalmers University of Technology, Department of Technology, Managment and Economics, Vera Sandberg Allee 8, 41133 Gteborg, Sweden. E-mail: hasbi@chalmers.se

$\dagger_{i}$ 3/Telecom Paris/Economics and Social Sciences, 46 rue Barrault, 75634 Paris Cedex 13, France; antoine.dubus@telecom-paris.fr. 


\section{Introduction}

Developing economies, especially in Sub-Saharan Africa, have become a new El Dorado for telecommunication operators. With their flourishing and dynamic markets, they show promising prospects in terms of return on investment. The mobile telecommunication market is booming, the young generation is getting more and more connected and the digitalization of the society is on the priority list of governments.

Broadband technologies have been praised worldwide to be key drivers of economic growth and social development. Many countries have adopted broadband plans to ensure that the economic and social benefits stemming from these new technologies will spread out into their national economy. Developing economies are no exceptions. Through the definition of these broadband plans they set ambitious targets in terms of network deployment and coverage 11 However, very little is said on the demand-side. It is the role of a public authority to ensure that the supply-side effectively deploys the technology throughout the territory. But it is also its role to ensure that the technology is adopted or used by the population. The benefits expected from these new technologies will only materialize if there is a demand.

The contribution of this paper is to highlight what the determinants of mobile broadband use are in emerging economies. We provide policy makers with tools to ensure that the coverage of their territory with next generation mobile technologies is followed by their adoption and use by households. Developing economies bear their own specificities and cannot be compared to western economies. An understanding of these mechanisms would greatly help policy makers to ensure not only the complete coverage of their territories but also the uptake of mobile broadband by the population.

The analysis is performed using micro-level data coming from household surveys in four Sub-Saharan countries, namely Nigeria, Kenya, Tanzania and Uganda, over 5 years, from 2013 to 2017 2 These countries are good candidates for this analysis as they are politically stable and representative of developing countries which attract foreign direct investment, especially in the telecommunication sector ${ }^{3}$ They also provide a broad picture of the states of technology adoption in developing economies. Nigeria and Kenya have similar profiles. They are the most developed with a higher rate of mobile phone and SIM card ownership. But while Kenya ranks first in terms of mobile money use, it is not so common in Nigeria. In

\footnotetext{
${ }^{1}$ National broadband plans:

For Kenya: The national broadband strategy: Kenya vision 2030, 2013.

For Nigeria: The national broadband plan 2013, now version 2018.

For Tanzania: National Information Communication and Technology Broadband Backbone (NICTBB), 2014.

For Uganda: Draft National Broadband Strategy 2016-2020, date of the version unknown.

${ }^{2}$ Nigeria is located in west Africa and is the most populated country in Africa, with approximately 197 million inhabitants in 2019. Kenya, Tanzania and Uganda are located in east Africa in the Great Lakes region and are less populated with, in 2017, 49.7 million, 57.7 million and 42.56 million inhabitants respectively.

${ }^{3}$ Nigeria is a stable country when it comes to politics: the political regime is a democracy, stable since its introduction in 1999. While Tanzania and Uganda are stable politically, Kenya has experienced more political uncertainty. It has a new constitution since 2010 which led to a first election in 2013.
} 
both countries, the use of mobile Internet is the most probable. The countries already show encouraging signs of a potential quick increase of penetration rates. Tanzania and especially Uganda are the least penetrated countries, with a large proportion of non-mobile owners and non-SIM card owners. In all countries, (low-scale) agriculture is a key sector of the economy with a strong dependency on export of primary commodities. The population growth rate and the infantile mortality rate are high as it is the case in developing countries. The income per capita is low and there are large pockets of the population still living under the poverty level $4^{4}$

Nigeria is one of the countries with the highest number of extreme poor in the world 5 In Tanzania, the poverty level is decreasing, but not in absolute numbers due to the high population growth. However, financial inclusion is increasing with $62 \%$ of the population financially included in 2017 . It is the second country in terms of mobile money use ${ }^{6}$ In Uganda, the level of poverty is rising along with infantile mortality $]^{7}$ The poor weather conditions paired with the conflicts in neighboring countries and the difficulty to conduct business for the private sector had a negative impact on Uganda's economic growth 8 The economic growth rate stagnated around $4.5 \%$ from 2011, while it culminated at $7 \%$ in the 1990's and early 2000's. However, the economic growth has been increasing again in the latter part of 2017 largely driven by growth in ICTs and better weather conditions favorable to agriculture. Financial inclusion is progressing in Uganda with mobile money being the most popular service with $43 \%$ of the adult population having a mobile money account.

In 2018, Kenya was one of the fastest growing economies in Sub-Saharan Africa with high agriculture exportation, low oil prices, tourism and strong remittances. The Nigerian economy performs well, with an average growth rate of $5.7 \%$ between 2006 and 2016, driven up by the exportation of natural resources. The economy slowed down recently, with a recession in 2016, and growth rates of $0.8 \%$ in 2017 and $1.9 \%$ in 2018 9 Unemployment is very high, as it reached $23 \%$ of the working force in the end of 201810

We show that the ownership of a SIM card is one of the strongest determinants of mobile broadband use, maybe due to the fact that the owners of a SIM card are also the one paying for the service. However, we highlight the importance of device sharing especially in poorer countries like Tanzania and Uganda, but also in large households in Nigeria. Sharing practices are hugely contributing to increasing mobile broadband use. We also highlight the presence of positive effects coming from the use of other technologies.

\footnotetext{
${ }^{4}$ Except from Nigeria which is a lower middle-income country, the other countries belong to the low-income group.

${ }^{5}$ Source: World Bank 2019.

${ }^{6}$ The transaction value-to-GDP ratio reaches $53 \%$ in 2017.

${ }^{7}$ Uganda is hosting 800,000 refugees from South Sudan and 1.35 million refugees in total making it the largest refugee host in Africa.

${ }^{8}$ Uganda suffers from the consequences of the civil war in South Sudan and the conflicts in the Democratic Republic of Congo.

${ }^{9}$ Data are available on World Bank.

10 IMF, World Economic Outlook.
} 
Indeed, those using mobile money or owning a bank account are also more likely to use mobile broadband. That may be explained by the easiness of access or use of these services via mobile Internet. Therefore, by creating positive spillovers among ICTs and financial technologies, mobile broadband could be seen as a way to increase financial inclusion.

However, we show that those more likely to be excluded from mobile broadband use are the eldest, those with the lowest level of education, and in particular women. Mobile broadband is used in different ways depending on countries. In particular, focusing on non-mobile owners in Nigeria, we show that the unemployed have a higher chance to use mobile broadband. This positive relation supports the idea that mobile Internet is used for job search practices. This is not true in the other countries considered.

These results have strong policy implications. A first step in order to encourage the use of mobile broadband technologies and allow the most vulnerable to reap their expected benefits would be to facilitate access to mobile phones, SIM cards, as well as mobile financial services. We also argue that filling the digital gap requires more intense investments in mobile network coverage.

The remainder of the paper is organized as follows. Section 2 discusses the relevant literature on ICTS and especially mobile broadband adoption and uses. Section 3 provides an overview of the countries' telecommunications market. Section 4 presents the data while Section 5 introduces the econometric framework. Section 6 presents the estimation results. Finally, Section 7 concludes.

\section{Literature Review}

So far the literature has mostly focused on the drivers of mobile phone adoption and mobile phone use in developing economies and especially in Africa (see for instance Van Biljon and Kotzé (2007), Kalba (2008), Aker and Mbiti (2010), Blumenstock and Eagle (2010)). However, because of its novelty, mobile broadband has yet not been studied in depth, despite the fact that its positive effects should be higher than fixed broadband (Thompson Jr and Garbacz, 2011). We review here the literature on ICT adoption, uses and impacts.

\subsection{Adoption}

Overall, authors find that GDP, income, low inequality, availability of infrastructure and education are driving ICT adoption(Bagchi and Udo, 2007). Receiving foreign direct investments (FDI) is also positively correlated to ICT adoption (Kyobe, 2011). Brown and Licker (2003) show that social factors influence the decision to adopt new technologies. Higher social groups would be more sensitive to factors such as perceived usefulness, enjoyment, and long term profitability, while perceived usefulness and ease of use 
will be positively correlated with ICT adoption for the most vulnerable households.

As regards fixed Internet, Oyelaran-Oyeyinka and Adeya (2004) highlight the importance of the computer cost in the decision to adopt fixed broadband. They also show that to avoid a costly computer ownership, users turn to Internet cafe or use computers at friends or colleagues' places, which is in line with Rangaswamy and Cutrell (2012).

Besides, Birba and Diagne (2012) and Touray et al. (2015) show that other factors such as education, gender, and social network membership play an important role. Overall, Internet is adopted mostly by young educated people familiar with the uses of technology (Pénard et al., 2012).

The use of mobile Internet, requires fewer skills and less financial resources than fixed Internet and is not conditioned to home electricity (Donner et al., 2011; Stork et al., 2013). However, Chigona et al. (2009) highlight that socially excluded households in South Africa have limited awareness of the existence and potential uses of mobile Internet. On top of this informational issue, cell phone cost has a strong negative influence on respondents decision to use mobile Internet.

Focusing on smartphone owners, Mathur et al. (2015) emphasize how the cost of data hinders mobile Internet use. They show that regulating the easiness of smartphone acquisition, the cost of data as well as educating the population to use mobile Internet could remove the barriers remaining for mobile Internet adoption. They recommend notably to educate the population to use mobile Internet as a practical tool for networking on social media, information gathering and job seeking.

\subsection{Uses}

We now turn to ICT uses by the population, in order to better understand why these technologies are adopted. Authors find that overall ICTs enhance communication practices such as financial support between family members, and everyday coordination activity (Oduor et al. 2014).

Focusing on mobile phones, authors find that they are major actors of emancipations of the most vulnerable (Murphy and Priebe, 2011) 11 Phones can be easily shared (Burrell, 2010, Wyche and Olson, 2018), enabling the poorest to contact friends and family, and even to require remittances. In particular, the effects of mobile phones are increasingly driven by mobile-based services for money transfers such as M-PESA, well developed in Sub-Saharan Africa 12 Such services allow for immediate money transfers in case of shock, and thus allow family members to support each other (Morawczynski, 2009).

Researchers find various uses of Internet depending on the age or activities of users. The youngest tend to use Internet for leisure, while college educated individuals use it for information gathering (Penard

${ }^{11}$ In 2007 for the most vulnerable women in rural Kenya.

${ }^{12}$ An extensive literature focuses on the factors of adoption of different mobile financial services (MFS) (Donner and Tellez |2008|| Mas and Morawczynski||2009||Demombynes and Thegeya|| 2012||Hove and Dubus||2019). 
et al. 2015). With the emergence of mobile Internet a lot of activities are taken out of Internet cafes to be used on mobile phones (Rangaswamy and Cutrell, 2012). Women use mobile Internet for entertainment and connection (Donner et al., 2011). Focusing specifically on Facebook, (Wyche et al., 2013) shows that users look for formal and informal jobs, market themselves or seek efficiently remittances from friends and family abroad.

However, these effects are to be nuanced as vulnerable parts of the population, such as rural women, are still excluded from mobile Internet use. For instance they often use an old mobile phone with low battery capacity, and thus cannot use mobile Internet even though their device incorporates the functionality (Wyche and Olson, 2018).

\section{Telecommunications Market in Sub-Saharan Africa}

In developing countries, the fixed telephone network coverage is limited and covers mostly urban areas. The penetration rate of fixed telephony is rather low and does not reach $1 \%$ in any of the countries considered. The subscription rate to the fixed telephony has remained very low since 2000 and hardly reached $2 \%$ in Kenya in 2008 13 The telecommunications market is mostly driven by the use of mobile phones. The penetration rate of mobile phone is rapidly increasing. The boom in mobile phone subscriptions has surprised the telecommunication operators themselves. As a well cited example, Safaricom, a national operator in Kenya, projected to reach 3 million subscribers by 2020, but reached 14 million customers in 2010. The spectacular growth of the mobile market has been primarily driven by the liberalization of the telecommunications markets, which have been progressively opened-up to competition along with the introduction of independent regulatory authorities. Another important factor in East Africa has been the introduction of mobile money services, which enable everyone using a mobile phone to make financial transactions, to store money and even to start or expand their own business. These services have been exceptionally well received because a large proportion of households, notably in Sub-Saharan Africa, is excluded from the banking system or does not wish to be part of it. Besides, the use of mobile money services does not require broadband, which makes the services even more attractive, and thus boosting mobile phone adoption.

\footnotetext{
${ }^{13}$ Source International Telecommunication Union databases,2018.
} 
Figure 1: Mobile-cellular telephone subscriptions per 100 inhabitants.

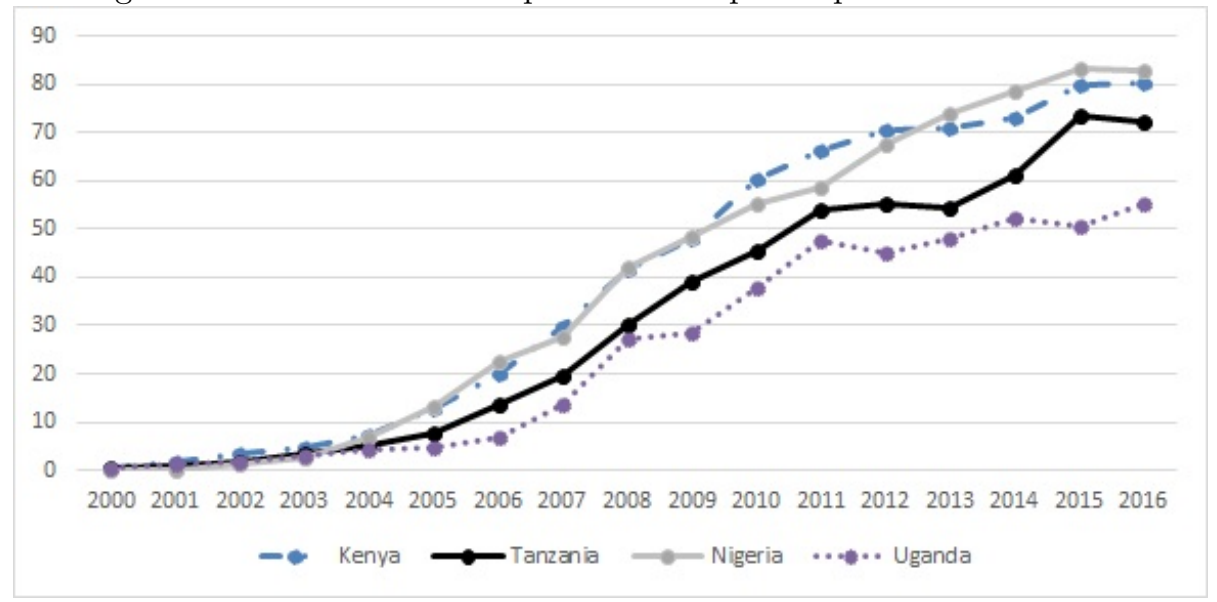

Source International Telecommunication Union databases,2018.

In Kenya and Nigeria, the mobile subscription growth rate has been very high. In 2005, around $10 \%$ of the population had a mobile phone subscription, while in 2016, more than $80 \%$ have one. In Uganda, the rise of mobile phone subscriptions has been of a slower pace. In 2005, less than $5 \%$ of the population had a mobile phone subscription, in 2016 it is a bit more than half of the population which has a subscription.

The figures here are not representative of mobile phone use by the population. In developing economies, a mobile phone is not considered as an individual device as it is in Europe or in the US. It can be shared among several people, either within a household or a community. It is not rare to have individuals owning a SIM card, but no mobile phone. They would make use of someone else's mobile phone. Others may not have a SIM card but use the one of someone else. In developing economies and specifically in Sub-Saharan Africa, where the poverty level remains high, there are still households which cannot afford to purchase a mobile device ${ }^{14}$

Internet use has also become more popular in developing economies with approximately one fourth of the population using it in Kenya, Nigeria and Uganda. Tanzania is still lagging behind with only $13 \%$ of the population making use of the Internet in 2016. Considering the low rate of fixed-broadband subscriptions, individuals access the Internet using wireless technologies, with mobile broadband becoming increasingly popular. Figure 2 shows the evolution of Internet use over from 2000 to 2016.

\footnotetext{
14"Poverty in a Rising Africa", Africa Poverty 2016 Report, World Bank.
} 
Figure 2: Percentage of Individuals using the Internet.

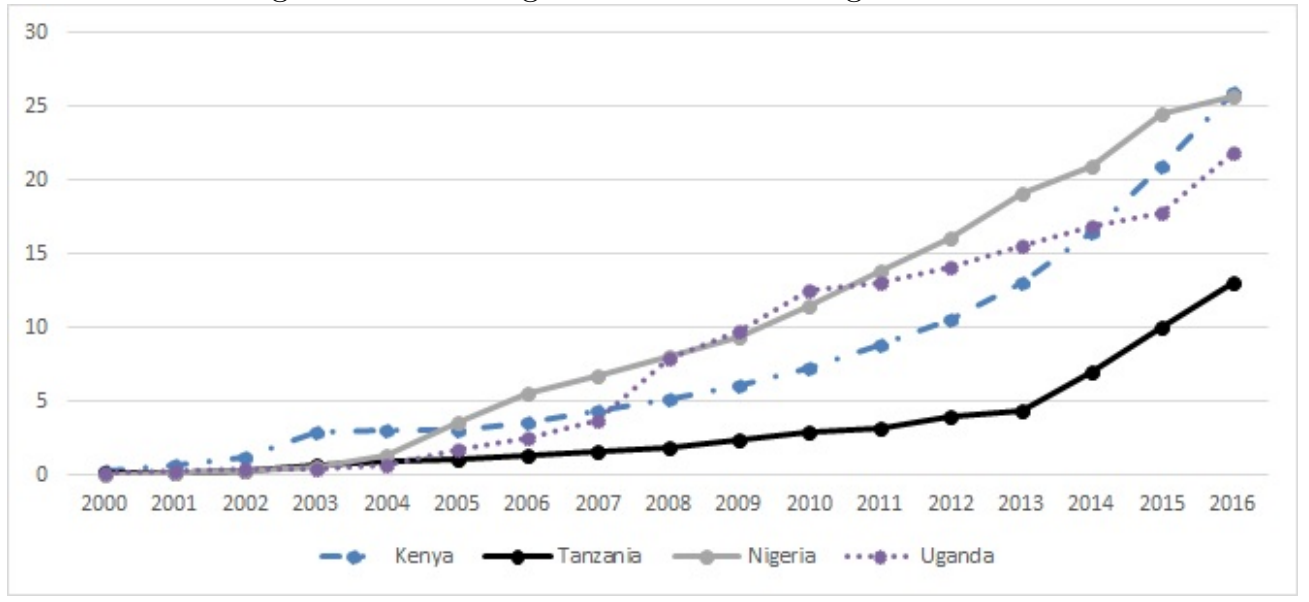

Source International Telecommunication Union databases,2018.

While all countries benefit from a good GSM $(2 \mathrm{G})$ coverage, the UMTS (3G) coverage is more limited and the LTE (4G) technology starts to be introduced onto the markets. Table 1 shows the percentage of the population covered by $2 \mathrm{G}, 3 \mathrm{G}$ and $4 \mathrm{G}$ mobile networks respectively. Based on the Inclusive Internet Index: Measuring Success 2018, "the mobile network coverage refers to the percentage of inhabitants within range of a mobile-cellular signal; irrespective of whether or not they are subscribers or users".

Table 1: Mobile network coverage in 2018, in percentage of the population

\begin{tabular}{|c|c|c|c|c|}
\hline & Nigeria & Kenya & Tanzania & Uganda \\
\hline $2 \mathrm{G}$ & $93 \%$ & $99 \%$ & $95 \%$ & $93 \%$ \\
$3 \mathrm{G}$ & $54 \%$ & $78 \%$ & $85 \%$ & $64 \%$ \\
$4 \mathrm{G}$ & $51 \%$ & $22 \%$ & $13 \%$ & $15 \%$ \\
\hline
\end{tabular}

Source: The Inclusive Internet Index: Measuring Success 2018.

In Nigeria, while big cities such as Abuja, Lagos and Kano, as well as their neighboring areas benefit from high quality signals, rural areas lag behind with, in most cases, almost no connectivity. This structural factor may be the biggest hinder for mobile Internet adoption in rural areas. 
Figure 3: Mobile networks coverage in Nigeria, by all networks: 2G, 3G and 4G (left) and by 4G (right).
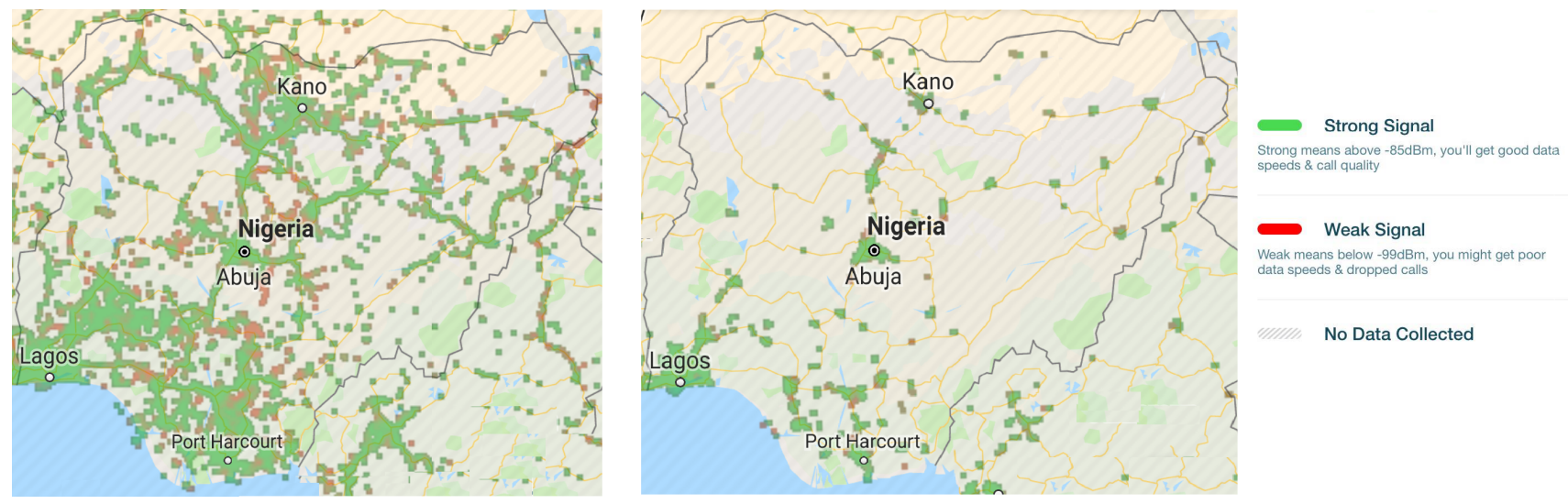

Source Open Signal, 2019.

The figure on the left shows the areas in which there is a mobile connectivity. The figure in the middle shows the areas in which the is a $4 \mathrm{G}$ connectivity. The green dots represents a strong signal and the red ones a weak signal. The maps have been crowdsourced by users.

Having a look at Kenya, Tanzania and Uganda, we clearly see the same patterns with areas located close to the capital cities and the most touristic areas well deserved with all kind of mobile broadband technologies, including 4G. 
Figure 4: Mobile networks coverage in Kenya, Tanzania and Uganda, by all networks: 2G, 3G and 4G (left) and by $4 \mathrm{G}$ (right).
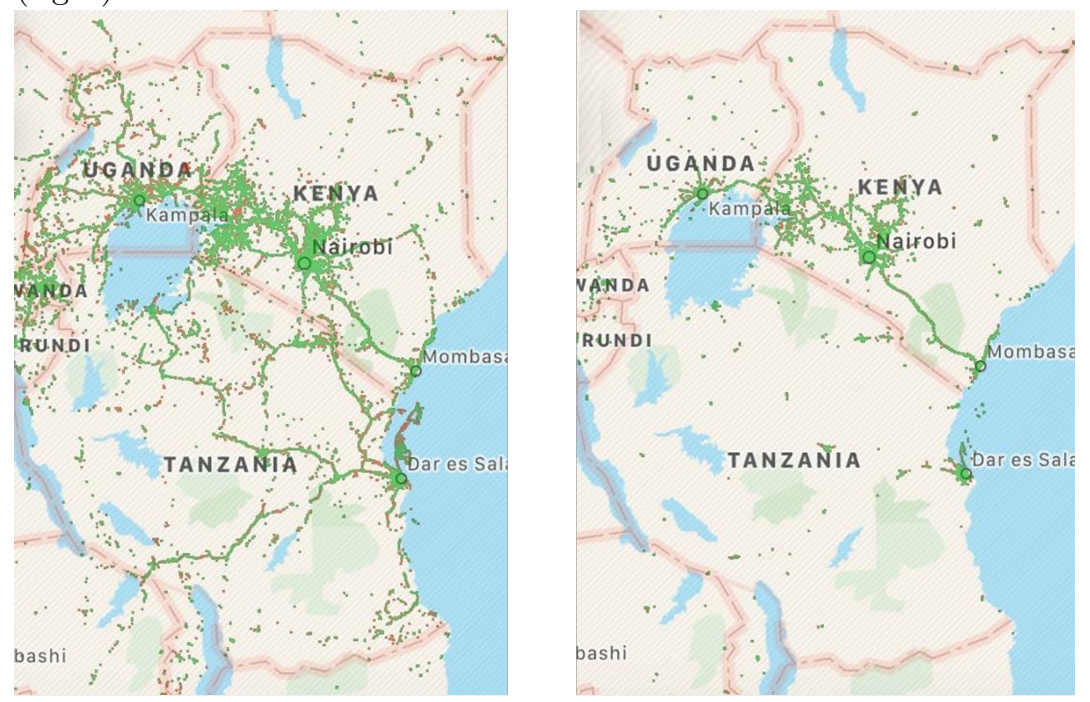

Source Open Signal, 2019.

The figure on the left shows the areas in which there is a mobile connectivity. The figure in the middle shows the areas in which the is a $4 \mathrm{G}$ connectivity. The green dots represents a strong signal and the red ones a weak signal. The maps have been crowdsourced by users.

\section{Data}

We exploit a survey led by Intermedia's financial Inclusion Insights program, providing data representative of the national population for Nigeria, Kenya and Uganda (separately). Data are at the household levels and households are chosen randomly, based on the national census. The survey has been conducted either in English or in the national or regional language spoken by the respondent. We have data over five years, from 2013 to 2017, on more than 30,000 individuals for Nigeria and on more than 15,000 individuals for both Kenya and Uganda. Data on more than 12,000 individuals are available for the years 2014 to 2017 for Tanzania $\sqrt{15}$ Summary statistics are displayed in Annex.

Each cross-section contains information on mobile phone use, access and ownership. We also have data on SIM card ownership and access. We have information on household's financial inclusion with data on mobile money use and account ownership and access; on bank account ownership, access and use. The survey provides us with data on household's appliances and level of wealth. The databases contain also socio-demographical information on gender, age, socio-professional occupation, years of education

\footnotetext{
${ }^{15}$ Data on mobile broadband use are unavailable for the year 2013.
} 
and localization among others.

In our weighted sample, on average between 2013 and 2017 around $80 \%$ of the respondents own a mobile phone in Nigeria and in Kenya; in Uganda they are slightly more than half. On average, between 2014 and 2017, around two third of the respondents in Tanzania own a mobile device. Almost everyone owning a mobile phone owns an active SIM card. SIM card ownership seems to be slightly more popular than mobile phone ownership in all four countries. Access to a mobile phone is more popular in Tanzania and in Uganda with one fourth of the respondent in both countries accessing the mobile device of someone else. Figures 5 to 8 show the proportions of individuals in our sample owning, accessing or not having a mobile phone and/or a SIM card.

Table 2 shows that about one third of mobile owners use the Internet in Nigeria and in Kenya. Internet use is less democratized in Tanzania and Uganda, which is reflected by the lower rate of Internet users in these two countries with one fifth and one fourth of the respondent respectively. The statistics show also that mobile money services are highly used in East Africa compared to Nigeria.

Having a closer look at the composition of the mobile owners and non-mobile owners populations, we see that mobile owners are quite equally distributed between urban and rural areas, with a slight majority of those living in rural areas, except for Uganda where $69 \%$ of mobile owners live in rural areas ${ }^{16}$ Besides, mobile owners are somehow equally distributed between genders. However, almost three quarter of them live below the poverty level in Nigeria and in Tanzania.

As regards the non-mobile owners' population, Table 2 shows that the vast majority of them do not use the Internet. The proportion of those using the Internet ranges between $2 \%$ and $7 \%$. Except in Kenya, where mobile money is extremely spread into the population, the proportion of respondents using these services is of a lower magnitude. Around $80 \%$ of non-mobile owners are found in rural areas. A gender gap is observed here as non-mobile owners are mostly composed of women. Besides, non-mobile owners are primarily living under the poverty level.

\footnotetext{
${ }^{16}$ Uganda is the most rural country in our sample with $76 \%$ of Ugandan adults living in a rural area.
} 
Table 2: Proportions of individuals owning a mobile or not owning a mobile depending on different characteristics for the years 2013-2017 for all countries but Tanzania (2014-2017).

\begin{tabular}{|l|c|c|c|c|}
\hline & \multicolumn{2}{|c|}{ Nigeria } & \multicolumn{2}{c|}{ Kenya } \\
\hline \hline & Ownership & Non-Ownership & Ownership & Non-Ownership \\
\hline Internet users & $34 \%$ & $7 \%$ & $29 \%$ & $7 \%$ \\
Robile money users & $1.6 \%$ & $0.3 \%$ & $92 \%$ & $39 \%$ \\
Male & $59 \%$ & $72 \%$ & $60 \%$ & $77 \%$ \\
$15-25$ & $53 \%$ & $35 \%$ & $51 \%$ & $41 \%$ \\
$25-34$ & $31 \%$ & $40 \%$ & $31 \%$ & $53 \%$ \\
Over 55 & $29 \%$ & $19 \%$ & $29 \%$ & $17 \%$ \\
Below poverty & $10 \%$ & $16 \%$ & $12 \%$ & $12 \%$ \\
\hline \hline \hline & $73 \%$ & $83 \%$ & $37 \%$ & $69 \%$ \\
\hline \hline & \multicolumn{2}{|c|}{ Tanzania } & \multicolumn{2}{c|}{ Uganda } \\
\hline Internet users & $22 \%$ & $4 \%$ & $16 \%$ & $2 \%$ \\
Mobile money users & $58 \%$ & $26 \%$ & $72 \%$ & $21 \%$ \\
Rural & $63 \%$ & $79 \%$ & $69 \%$ & $87 \%$ \\
Male & $54 \%$ & $36 \%$ & $55 \%$ & $37 \%$ \\
$15-25$ & $26 \%$ & $39 \%$ & $30 \%$ & $39 \%$ \\
$25-34$ & $29 \%$ & $23 \%$ & $29 \%$ & $21 \%$ \\
Over 55 & $12 \%$ & $13 \%$ & $9 \%$ & $17 \%$ \\
Below poverty & $77 \%$ & $90 \%$ & $51 \%$ & $83 \%$ \\
\hline
\end{tabular}

Own weighted statistics.

\section{$5 \quad$ Econometric Model}

To answer our question about the drivers of mobile broadband use in developing countries, we develop first a discrete choice model with time and region effects which is estimated on the four countries together. Then we estimate a second discrete choice model with time and region effects for each country to point out country's differences.

Then, we have:

$$
\begin{array}{r}
{\text { mobile_b } b_{i j t}=\alpha+}_{\alpha} \beta_{1} \text { own_mobile }_{i j t}+\beta_{2} \text { cat_sim }_{i j t}+\beta_{3} \text { social_media }_{i j t}+\beta_{4} \text { m_money } \text { ijt }_{-} \\
+\beta_{5} \text { bank_account }_{i j t}+\beta_{6} \text { urban }_{i j t}+\beta_{7} \text { male }_{i j t}+\beta_{8} \text { age }_{i j t}+\beta_{9} \text { educ }_{i j t} \\
+\beta_{10} \text { socio_pro }_{i j t}+\beta_{11} \text { ppi_score }_{i t}+\text { year }_{t}+\eta_{k}+\epsilon_{i j t},
\end{array}
$$

where $m_{0}$ obile_b $b b_{i j t}$ is a dummy variable representing mobile broadband use by respondent $i$ in country $j$ at time $t$, either on its own phone or on a phone he/she has borrowed, at time $t$. Mobile broadband use 
could be influenced by the possession of a mobile phone, denoted by own_mobile. It equals 1 if respondent $i$ in country $j$ owns a telephone at time $t$ and 0 if he/she has access to a mobile device. We also introduce a categorical variable to indicate whether the respondent owns an active SIM card or has access to one. It is denoted by cat_sim $i j t$ and equals 2 if respondent $i$ in country $j$ owns a SIM card at time $t, 1$ if he/she has access to a SIM card and 0 otherwise. We also control for mobile money use, denoted m_money, and the ownership of a bank account. It gives us an indication on how financial inclusion impacts mobile broadband use. Besides, mobile money services have been driving mobile phone adoption in East Africa and may also play a role as regards mobile broadband use. Even though the use of a mobile money services does not require broadband, users can acquire some skills and be more comfortable using other applications.

Socio-demographical characteristics may influence mobile broadband use. It may be more common to use mobile broadband in urban areas. The gender of the respondent is also taken into account, as well as the age category. The variable age has five categories, 15-24 years old, 25-34 years old, 35-44 years old, 45-54 years old and over 55 years old. We include the young users as on average, between 2014 and $2017,39 \%$ of the $15-24$ years old and $23 \%$ of the $15-18$ years old uses the Internet.

The level of education may also affect the decision to use mobile broadband by an individual, as it requires specific digital and literacy skills. The level of education, denoted educ, consists of four different levels, no formal education, primary education, secondary education and tertiary education. The PPI, a measurement of the poverty level, is included to take into account the level of poverty of the household. The socio-professional group, denoted by socio_pro may also have an impact on mobile broadband use. White collars may use mobile broadband more than retired for example. This variable consists of eight categories: Farmers (Group 1), Craftsmen and Self-employed (Group 2), White collars (Group 3), Intermediated professions (Group 4), Manual workers (Group 5), Military (Group 6), Unemployed (Group 7) and Students (Group 8).

$\eta_{k}$ is a region dummy capturing cross-region differences. year is a dummy variable for each year capturing potential time-effects. Finally, $\epsilon_{i j t}$ is an error term clustered at the state (or province) level.

We add to this specification a categorical variable measuring the number of households members, for Nigeria and Kenya, to estimate whether living in a larger family has an impact on mobile broadband use. The information was not available for Tanzania and Uganda. For Nigeria, we add a control for the ownership of a television, which is mostly considered as an entertainment platform. 


$$
\begin{aligned}
& \text { mobile_b }_{i j t}=\alpha+\beta_{1} \text { own_mobile }_{i j t}+\beta_{2} \text { cat_sim }_{i j t}+\beta_{3} m_{-} m_{\text {money }}+\beta_{4}+\beta_{4} \text { bank_account }_{i j t} \\
& +\beta_{5} \text { urban }_{i j t}+\beta_{6} \text { male }_{i j t}+\beta_{7} \text { age }_{i j t}+\beta_{8} \text { educ }_{i j t}+\beta_{9} \text { socio_pro }_{i j t} \\
& +\beta_{10} \text { ppi_score }_{i t}+\beta_{10} \text { television }_{i j t}+\beta_{11} n b_{-} h h_{i j t}+\text { year }_{t}+\eta_{k}+\epsilon_{i j t},
\end{aligned}
$$

Considering that almost one fifth of the population does not own a mobile device. We also estimate more specifically what the determinants of mobile broadband use are in the sub-population of non-mobile owners.

$$
\begin{aligned}
\text { mobile_bb }_{i j t}=\alpha+ & \beta_{1} \text { cat_sim }_{i j t}+\beta_{2} \text { m_money }_{i j t}+\beta_{3} \text { bank_account }_{i j t} \\
& +\beta_{4} \text { urban }_{i j t}+\beta_{5} \text { male }_{i j t}+\beta_{6} \text { age }_{i j t}+\beta_{7} \text { educ }_{i j t} \\
+ & \beta_{8} \text { socio_pro }_{i j t}+\beta_{9} \text { ppi_score }_{i t}+\text { year }_{t}+\eta_{k}+\epsilon_{i j t},
\end{aligned}
$$

An insight on this specific question seems highly relevant for policy makers, who seek to reduce the digital divide in the population.

\section{Estimation Results}

Tables $9 \mathrm{a}$ to $9 \mathrm{~b}$ show that typical mobile broadband users in Sub-Saharan countries appear to be relatively young educated males ${ }^{17}$ Wealth has a positive and highly significant impact but is rather low in magnitude. Mobile broadband is mostly used by students, which is in line with previous literature. Pénard et al. (2012) show that students use the Internet for information gathering purposes. On the contrary, the unemployed and the farmers are the least likely to use mobile broadband. In addition, we show in tables 11a and 11b that the ownership of a television has a negative impact on mobile broadband use in Nigeria. As underlined in the literature, mobile broadband could be used for leisure and substitute to entertainment programs provided by television.

Intuitively, the results from specification (1) in in tables $9 \mathrm{a}$ and $9 \mathrm{~b}$ show that those owning a SIM card are more likely to use mobile broadband. Taking into account that in developing countries an important part of the population does not own a SIM card, but has access to one, shows that both ownership and access to a SIM card increase the probability of using mobile broadband. It is remarkable however that overall, owning a SIM card and only having access to one have effects of very close magnitudes (respectively 2.783 and 2.665). Sharing practices compensate the lack of ownership when it comes to mobile broadband uses.

\footnotetext{
${ }^{17}$ The estimations have been run without the PPI variable, the results are qualitatively similar.
} 
Turning to social media, we identify a strong positive relation with mobile broadband use. Being part of an online social community, such as Facebook or WhatsApp is strongly correlated with mobile broadband use. This can be explained by the fact that mobile Internet is a mean to access social networks, especially through mobile applications and online web pages. Social community has been shown in the literature to be an important part of social life in Sub-Saharan countries, being able to access online social community could be a mean to boost mobile broadband use. Birba and Diagne (2012) and Touray et al. (2015) show that social network membership plays an important role in the decision to adopt Internet.

When it comes to mobile financial services, our results suggest that mobile money users are more likely to use mobile broadband. In some African countries and East Africa essentially, mobile phone adoption has been primarily boosted by the introduction of mobile money services. Respondents that are the most likely to use mobile broadband are those who have been using mobile money for the longest time, or conversely, new adopters. On the one hand, those using mobile money for a long time may have gained more experience and are thus more inclined to switch to a more advanced version. This could underline the existence of a learning effect. On the other hand, respondents who adopted mobile money very recently are active mobile users, and thus have more chances to use other mobile technologies such as mobile broadband.

Mobile broadband use is also more common among bank account owners. This is probably due to two effects: the ownership of a bank account is a sign of relative wealth and bank account owners have more chance to have a (costly) access to mobile broadband. On the other hand, mobile Internet facilitates access to bank accounts by allowing respondents to open accounts online, and to make banking operations on their mobile phones. Hence we show a positive correlation between digital inclusion via mobile broadband use and financial inclusion with the use of either mobile money services or bank account.

We can identify regional specificities of mobile broadband uses by considering each country separately. In Nigeria, the type of employment has no impact on mobile broadband adoption and mobile money use has a very low impact, only for those using mobile financial services for more than a year. The effect of education is also much smaller. However, age, wealth, and structural factors such as SIM access and ownership have a much higher impact than in other countries. This difference probably stems from the very low penetration rate of mobile money services compared to the other countries considered.

In Uganda, Nigeria and Kenya, the impact of SIM access and SIM ownership are of very close magnitudes (4.221 and 4.220 for Uganda). This is not the case in Tanzania where SIM access has a higher impact than SIM ownership (1.143 and 0.655). This reflects the fact that sharing practices have a higher impact on mobile broadband use than in the other countries. Tanzania shows the lowest rate of Internet penetration, around $13 \%$ in 2016 against more or less $25 \%$ in other countries. Families who develop habits 
of sharing one SIM among members are more likely to have access to mobile broadband. By pooling the costs of a SIM, they can access more advanced technologies.

We also find in tables $11 \mathrm{a}$ and $11 \mathrm{~b}$, for Nigeria where the data is available, that the relative importance of accessing a mobile phone, compared to owning a mobile phone, increases with the number of households member ${ }^{18}$ Higher is the number of households member, higher is the likeliness to use mobile broadband if one has access to a mobile phone. This reflects the importance of device sharing in developing economies. Similarly, with a higher number of household members, the relative importance of owning a SIM card increases. However, we also find that even though the relative importance of accessing a mobile phone increases, those owning a mobile phone are still more likely to use mobile broadband 19 On the opposite, family size is uncorrelated with mobile broadband use in Kenya.

Living in urban or rural areas has no effect on mobile broadband use, except in Nigeria. Controlling for the regions, Table $9 \mathrm{a}$ highlights that households are more likely to use mobile broadband in the southern region, located right on the ocean shore. The northern region, which is the least developed and has suffered terrorist attacks from the Boko Haram radical Islamic groups, is the one with the lowest mobile broadband use. Naturally, the further we go back in time, the less probable it is for a respondent to use mobile broadband.

Focusing on non-mobile owners, we see in tables $10 \mathrm{a}$ and $10 \mathrm{~b}$ that the above effects are overall smaller. The effects of socio-demographic variables all decrease. For instance, gender is not significant anymore in Tanzania. Wealth also loses its significance in Kenya and Tanzania. This weakening of the effect is coherent with the literature (Hove and Dubus, 2019).

Finally, unemployment has ambiguous effects on mobile broadband use among non-mobile owners. In Nigeria, unemployment is positively correlated with mobile broadband use. This corroborates the use of mobile Internet for information gathering such as job seeking among those not owning a mobile phone (Mathur et al., 2015). Contrary to the rest of the population, when they use mobile Internet, as they need to ask for somebodies phone, they do not use Internet for leisure, but probably to look for a job.

\section{Conclusion}

Using micro-level data coming from household surveys in four Sub-Saharan countries, namely Nigeria, Kenya, Tanzania and Uganda, over 5 years, from 2013 to 2017, we estimate what the determinants of mobile broadband use are in developing economies. We have shown that overall, those who use mobile

\footnotetext{
${ }^{18}$ We also tested how the number of household's member impacted the relative effect of owning a mobile device or having access to one on mobile broadband use.

${ }^{19}$ Results are available upon request.
} 
broadband the least are the eldest, those with the lowest level of education, and in particular women. Our results highlight strong regional specificities that call for adapted answers from regulators and network operators.

Overall, mobile broadband is used for information gathering by student, or for leisure, but aggregated results let us suppose that mobile Internet may not be used for job search. However, this is not true anymore when focusing on non-mobile owners in Nigeria. This difference of uses may be due to the fact that mobile broadband is not understood as a tool for job search in Kenya, Tanzania and Uganda. In Nigeria where job search is implemented on mobile phones, the unemployed are more likely to use mobile broadband.

Regulators can encourage the use of mobile Internet among mobile users by lowering the price of data, as suggested Mathur et al. (2015). Campaigns of education of the population left behind might also help them overcome the technical barrier to mobile broadband use. Digital educational programs could be implemented at schools to familiarize the young generation to the use of the Internet. This is especially important as the young generation is the most likely to adopt the technology. Improving digital literacy among older groups could also encourage practices of information gathering by mobile users, and improve online job search practices.

The use of mobile broadband is also positively related to mobile money use and to the ownership of bank accounts. Encouraging mobile broadband penetration could thus remove barriers to financial inclusion.

Mobile ownership could be a limitation to the above positive effects of mobile broadband. We have shown that mobile phone sharing is a powerful way to address the issue of access to mobile broadband. These practices are well established in the population. However, sharing a mobile phone, for instance between members of a household, could raise inequality issues. For instance, if the owner of the mobile phone is the head of the family, other members may suffer from limited access, what we cannot capture with our data. More research is needed in this direction. 


\section{References}

Jenny C Aker and Isaac M Mbiti. Mobile phones and economic development in Africa. Journal of Economic Perspectives, 24(3):207-32, 2010.

Kallol Bagchi and Godwin Udo. Empirically testing factors that drive ict adoption in Africa and OECD set of nations. Issues in information systems, 8(2):45-52, 2007.

Ousmane Birba and Abdoulaye Diagne. Determinants of adoption of internet in Africa: Case of 17 Sub-Saharan countries. Structural Change and Economic Dynamics, 23(4):463-472, 2012.

Joshua Blumenstock and Nathan Eagle. Mobile divides: gender, socioeconomic status, and mobile phone use in Rwanda. In Proceedings of the 4th ACM/IEEE International Conference on Information and Communication Technologies and Development, page 6. ACM, 2010.

Irwin Brown and Paul Licker. Exploring differences in internet adoption and usage between historically advantaged and disadvantaged groups in south Africa. Journal of Global Information Technology Management, 6(4):6-26, 2003.

Jenna Burrell. Evaluating shared access: social equality and the circulation of mobile phones in rural Uganda. Journal of computer-mediated communication, 15(2):230-250, 2010.

Wallace Chigona, Darry Beukes, Junaid Vally, and Maureen Tanner. Can mobile internet help alleviate social exclusion in developing countries? The Electronic Journal of Information Systems in Developing Countries, 36 (1):1-16, 2009 .

Gabriel Demombynes and Aaron Thegeya. Kenyas mobile revolution and the promise of mobile savings. World Bank Policy Research Working Paper No WPS5988, 21:21, 2012.

Jonathan Donner and Camilo Andres Tellez. Mobile banking and economic development: Linking adoption, impact, and use. Asian journal of communication, 18(4):318-332, 2008.

Jonathan Donner, Shikoh Gitau, and Gary Marsden. Exploring mobile-only internet use: Results of a training study in urban south Africa. International Journal of Communication, 5:24, 2011.

Leo Van Hove and Antoine Dubus. M-pesa and financial inclusion in Kenya: Of paying comes saving? Sustainability, 11(3):568, 2019.

Kas Kalba. The adoption of mobile phones in emerging markets: Global diffusion and the rural challenge. International journal of Communication, 2:31, 2008.

Michael Kyobe. Investigating the key factors influencing ict adoption in south Africa. Journal of systems and information technology, 13(3):255-267, 2011. 
Ignacio Mas and Olga Morawczynski. Designing mobile money services lessons from m-pesa. Innovations: Technology, Governance, Globalization, 4(2):77-91, 2009.

Arunesh Mathur, Brent Schlotfeldt, and Marshini Chetty. A mixed-methods study of mobile users' data usage practices in south Africa. In Proceedings of the 2015 ACM International Joint Conference on Pervasive and Ubiquitous Computing, pages 1209-1220. ACM, 2015.

Olga Morawczynski. Exploring the usage and impact of transformational mobile financial services: the case of m-pesa in Kenya. Journal of Eastern African Studies, 3(3):509-525, 2009.

Laura L Murphy and Alexandra E Priebe. my co-wife can borrow my mobile phone! gendered geographies of cell phone usage and significance for rural Kenyans. Gender, Technology and Development, 15(1):1-23, 2011.

Erick Oduor, Carman Neustaedter, Tejinder K Judge, Kate Hennessy, Carolyn Pang, and Serena Hillman. How technology supports family communication in rural, suburban, and urban Kenya. In Proceedings of the 32nd annual ACM conference on Human factors in computing systems, pages 2705-2714. ACM, 2014.

Banji Oyelaran-Oyeyinka and Catherine Nyaki Adeya. Internet access in Africa: empirical evidence from Kenya and Nigeria. Telematics and Informatics, 21(1):67-81, 2004.

Thierry Pénard, Nicolas Poussing, Gabriel Zomo Yebe, and Nsi Ella. Comparing the determinants of internet and cell phone use in Africa: evidence from Gabon. 2012.

Thierry Penard, Nicolas Poussing, Blaise Mukoko, and Georges Bertrand Tamokwe Piaptie. Internet adoption and usage patterns in Africa: Evidence from Cameroon. Technology in Society, 42:71-80, 2015.

Nimmi Rangaswamy and Edward Cutrell. Anthropology, development and icts: slums, youth and the mobile internet in urban India. In Proceedings of the Fifth International Conference on Information and Communication Technologies and Development, pages 85-93. ACM, 2012.

Christoph Stork, Enrico Calandro, and Alison Gillwald. Internet going mobile: internet access and use in 11 African countries. info, 15(5):34-51, 2013.

Herbert G Thompson Jr and Christopher Garbacz. Economic impacts of mobile versus fixed broadband. Telecommunications Policy, 35(11):999-1009, 2011.

Almamy Touray, Airi Salminen, and Anja Mursu. Internet adoption at the user level: empirical evidence from the Gambia. Information Technology for Development, 21(2):281-296, 2015.

Judy Van Biljon and Paula Kotzé. Modelling the factors that influence mobile phone adoption. In Proceedings of the 2007 annual research conference of the South African institute of computer scientists and information technologists on IT research in developing countries, pages 152-161. ACM, 2007. 
Susan Wyche and Jennifer Olson. Gender, mobile, and mobile internet- Kenyan womens rural realities, mobile internet access, and Africa rising. Information Technologies \& International Development, 14:15, 2018.

Susan P Wyche, Andrea Forte, and Sarita Yardi Schoenebeck. Hustling online: understanding consolidated facebook use in an informal settlement in Nairobi. In Proceedings of the SIGCHI conference on human factors in computing systems, pages 2823-2832. ACM, 2013. 


\section{Appendix}

Table 3: Summary statistics for Nigeria (years 2013-2017)

\begin{tabular}{|l|ccccc|}
\hline \hline Variable & Obs. & Mean & Std. Dev. & Min & Max \\
\hline \hline Mobile broadband use & 30.397 & 0.306 & 0.461 & 0 & 1 \\
Urban & 30.397 & 0.384 & 0.486 & 0 & 1 \\
male & 30.397 & 0.554 & 0.497 & 0 & 1 \\
Age & 30.397 & 33.061 & 19.977 & 15 & 117 \\
Education & 30.397 & 2.707 & 0.992 & 1 & 4 \\
Number of household member & 30.397 & 3.035 & 1.770 & 1 & 6 \\
TV & 30.397 & 0.309 & 0.462 & 0 & 1 \\
Mobile only & 30.397 & 0.009 & 0.096 & 0 & 1 \\
SIM card only & 30.397 & 0.024 & 0.152 & 0 & 1 \\
Mobile and SIM card & 30.397 & 0.774 & 0.418 & 0 & 1 \\
No mobile phone. no SIM card & 30.397 & 0.193 & 0.395 & 0 & 1 \\
\hline \hline
\end{tabular}

Table 4: Summary statistics for Kenya (years 2013-2017)

\begin{tabular}{|l|lcccc|}
\hline \hline Variable & Obs. & Mean & Std. Dev. & Min & Max \\
\hline \hline Mobile broadband use & 15.111 & 0.223 & 0.416 & 0 & 1 \\
Urban & 15.111 & 0.378 & 0.485 & 0 & 1 \\
Gender (male) & 15.111 & 0.393 & 0.488 & 0 & 1 \\
Age & 15.111 & 35.606 & 14.939 & 15 & 98 \\
Education & 15.111 & 2.462 & 0.816 & 1 & 4 \\
Number of household member & 15.111 & 3.104 & 1.785 & 1 & 6 \\
Mobile only & 15.111 & 0.006 & 0.078 & 0 & 1 \\
SIM card only & 15.111 & 0.044 & 0.206 & 0 & 1 \\
Mobile and SIM card & 15.111 & 0.778 & 0.416 & 0 & 1 \\
No mobile phone, no SIM card & 15.111 & 0.172 & 0.377 & 0 & 1 \\
\hline \hline
\end{tabular}


Table 5: Summary statistics for Tanzania (years 2013-2017)

\begin{tabular}{|l|lcccc|}
\hline \hline Variable & Obs. & Mean & Std. Dev. & Min & Max \\
\hline \hline Mobile broadband use & 12,046 & 0.143 & 0.351 & 0 & 1 \\
Urban & 15,043 & 0.342 & 0.474 & 0 & 1 \\
Gender (male) & 15,043 & 0.439 & 0.496 & 0 & 1 \\
age & 12,046 & 35.737 & 14.674 & 15 & 100 \\
educ & 15,043 & 2.182 & 0.655 & 1 & 4 \\
m_only & 15,043 & 0.027 & 0.162 & 0 & 1 \\
active_sim y & 15,043 & 0.042 & 0.200 & 0 & 1 \\
m_active_sim & 15,043 & 0.668 & 0.471 & 0 & 1 \\
no_sim_phone & 15,043 & 0.212 & 0.408 & 0 & 1 \\
\hline \hline
\end{tabular}

Table 6: Summary statistics for Uganda (years 2013-2017)

\begin{tabular}{|l|ccccc|}
\hline \hline Variable & Obs. & Mean & Std. Dev. & Min & Max \\
\hline \hline Mobile broadband use & 15.002 & 0.086 & 0.280 & 0 & 1 \\
Urban & 15.002 & 0.248 & 0.432 & 0 & 1 \\
Gender (male) & 15.002 & 0.400 & 0.490 & 0 & 1 \\
Age & 14.476 & 34.9238 & 14.90364 & 15 & 100 \\
Education & 15.002 & 2.235 & 0.762 & 1 & 4 \\
Number of household member & 12.001 & 3.955 & 1.823 & 1 & 6 \\
Mobile only & 15.002 & 0.008 & 0.089 & 0 & 1 \\
SIM card only & 15.002 & 0.037 & 0.188 & 0 & 1 \\
Mobile and SIM card & 15.002 & 0.549 & 0.498 & 0 & 1 \\
No mobile phone, no SIM card & 15.002 & 0.406 & 0.491 & 0 & 1 \\
\hline \hline
\end{tabular}


Table 7: Weighted summary statistics for Nigeria, Kenya, Tanzania and Uganda respectively for the years 2013-2017; in percent

\begin{tabular}{|l|c|c|c|c|}
\hline \hline Variable & Nigeria & Kenya & Tanzania & Uganda \\
\hline \hline Mobile broadband use & 30.11 & 24.18 & 16.06 & 9.71 \\
Education & & & & \\
No Education & 15.85 & 9.17 & 10.87 & 13.68 \\
Primary & 15.20 & 42.01 & 63.18 & 50.71 \\
Secondary & 49.94 & 38.18 & 23.12 & 30.70 \\
Tertiary & 19.01 & 10.64 & 2.84 & 4.90 \\
Urban & 39.28 & 36.05 & 31.93 & 23.47 \\
Age & & & & \\
15-24 & 32.51 & 36.02 & 30.01 & 33.89 \\
$25-34$ & 27.44 & 25.90 & 27.23 & 25.51 \\
$35-44$ & 17.31 & 15.80 & 18.48 & 16.66 \\
$45-54$ & 11.46 & 10.12 & 11.67 & 11.05 \\
Over 55 & 11.10 & 12.16 & 12.27 & 12.88 \\
Gender (male) & 50.18 & 48.95 & 48.19 & 47.14 \\
TV & 64.74 & - & - & - \\
Mobile only & 1.11 & 0.72 & 2.69 & 0.85 \\
Active SIM card only & 1.93 & 4.39 & 4.14 & 3.83 \\
Mobile phone and SIM card & 83.29 & 75.97 & 65.57 & 55.29 \\
No mobile phone, no SIM card & 13.67 & 19.52 & 21.07 & 40.03 \\
\hline \hline
\end{tabular}

For all countries, except Tanzania, mobile broadband is measured for the years 2013-2017. For Tanzania, mobile broadband is measured for the years 2014-2017. 
Figure 5: Proportions of individuals in our sample for Nigeria and Kenya accessing or owning a mobile phone who either access or own a SIM card.

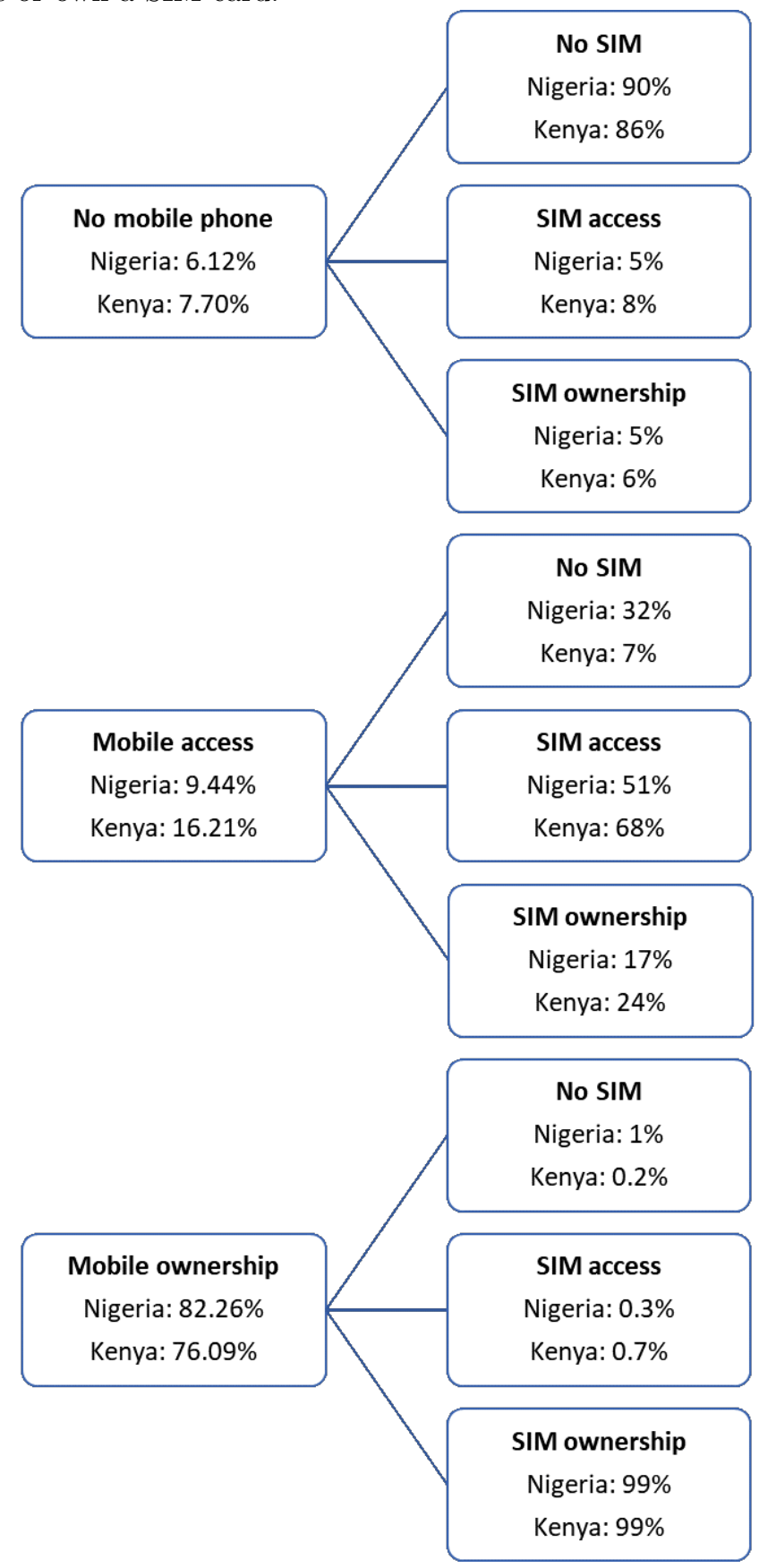

Own statistics: On the left part, from up to down. Proportion of individuals in our sample having no mobile phone, access to a mobile phone or owning a mobile phone which simultaneously have no SIM card, access to a SIM card or own a SIM card. On the right part, from up to down. Proportion of individuals in our sample having no SIM card, access to a SIM card or own a SIM card, which simultaneously have no mobile phone, access to a mobile phone or owning a mobile phone . 
Figure 6: Proportions of individuals in our sample for Tanzania and Uganda accessing or owning a mobile phone who either access or own a SIM card.

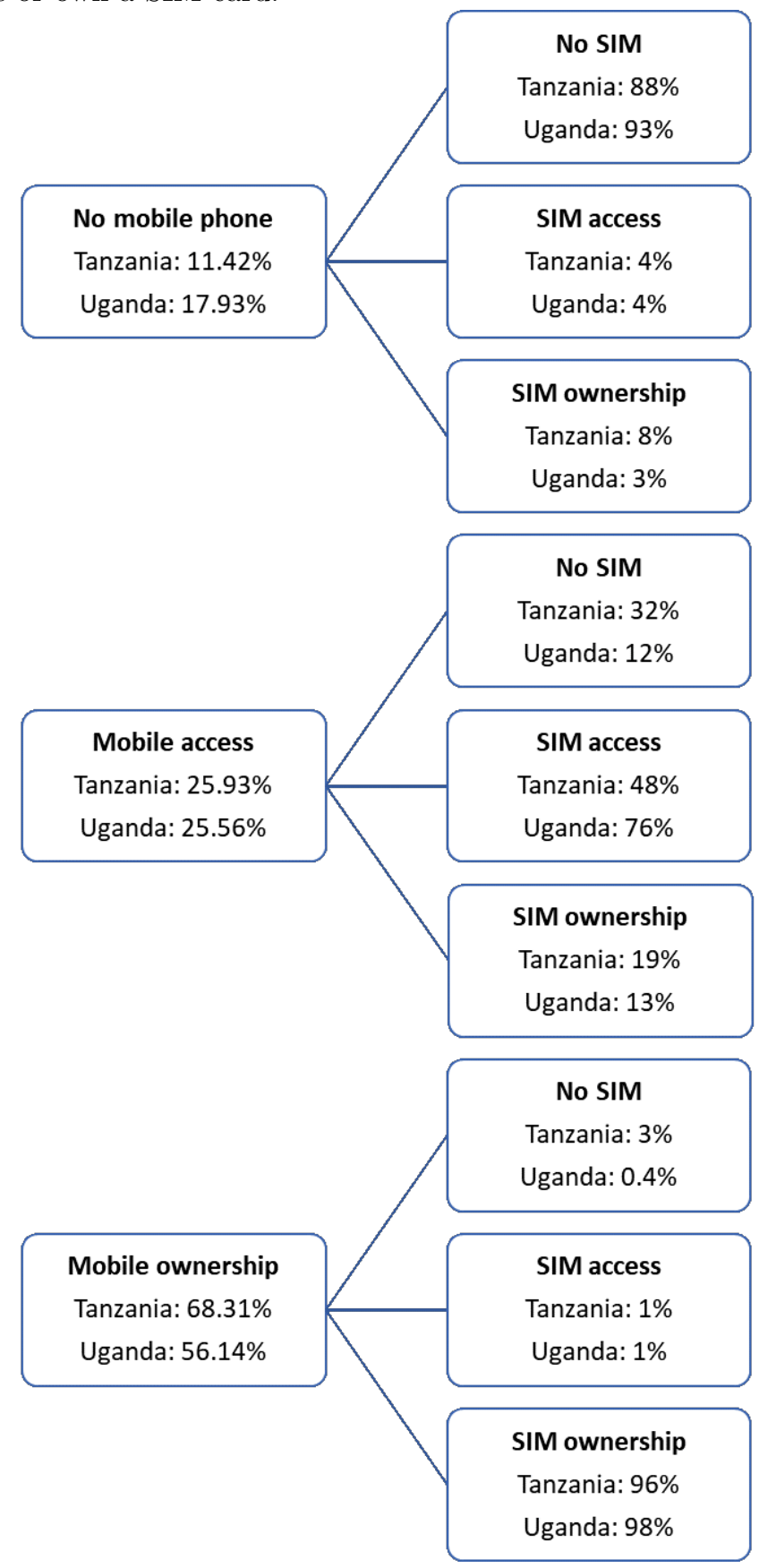

Own statistics: On the left part, from up to down. Proportion of individuals in our sample having no mobile phone, access to a mobile phone or owning a mobile phone which simultaneously have no SIM card, access to a SIM card or own a SIM card. On the right part, from up to down. Proportion of individuals in our sample having no SIM card, access to a SIM card or own a SIM card, which simultaneously have no mobile phone, access to a mobile phone or owning a mobile phone . 
Figure 7: Proportions of individuals in our sample for Nigeria and Kenya accessing or owning a SIM card who either access or own a mobile phone card.
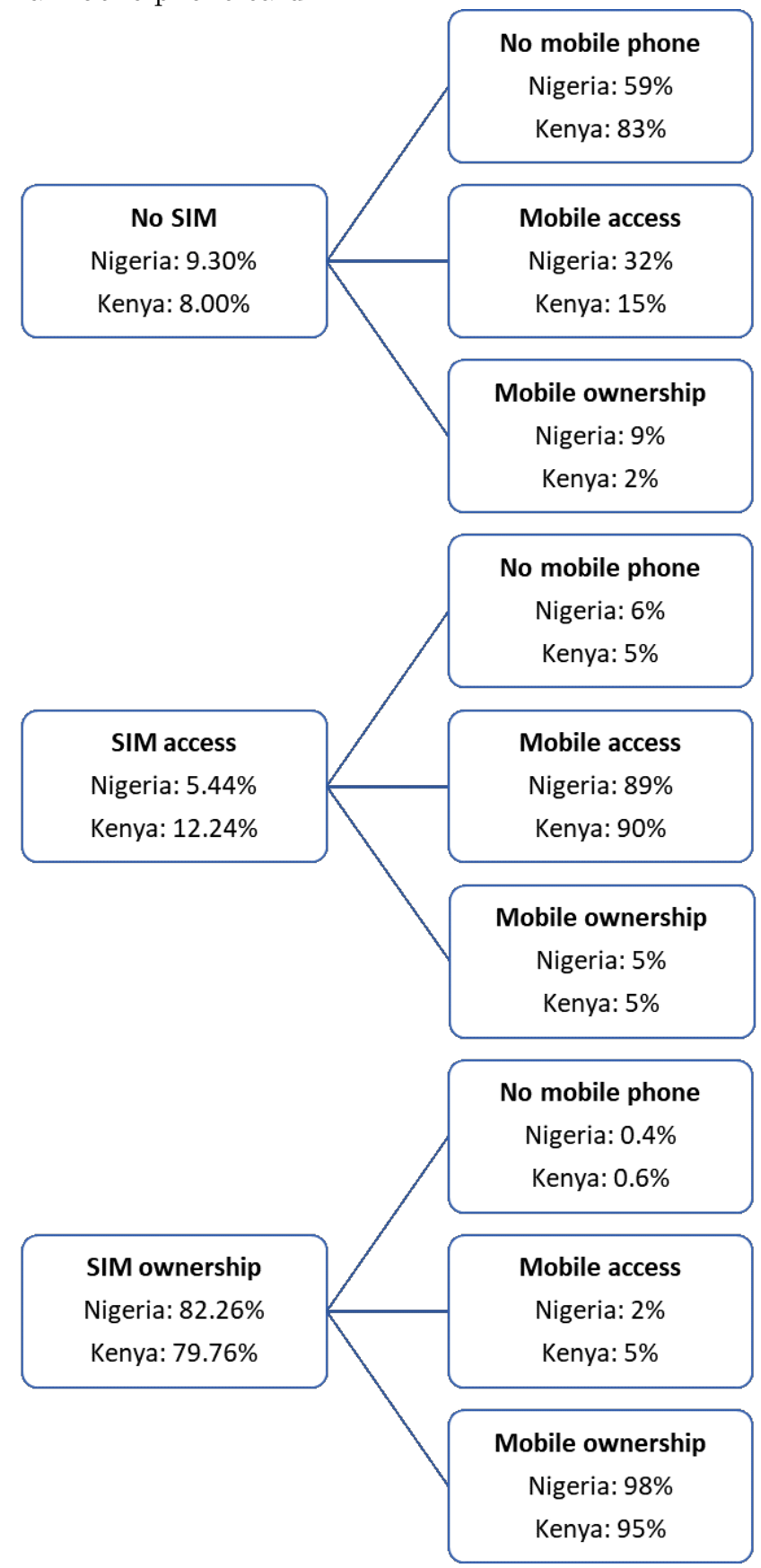

Own statistics: On the left part, from up to down. Proportion of individuals in our sample having no mobile phone, access to a mobile phone or owning a mobile phone which simultaneously have no SIM card, access to a SIM card or own a SIM card. On the right part, from up to down. Proportion of individuals in our sample having no SIM card, access to a SIM card or own a SIM card, which simultaneously have no mobile phone, access to a mobile phone or owning a mobile phone . 
Figure 8: Proportions of individuals in our sample for Tanzania and Uganda accessing or owning a SIM card who either access or own a mobile phone card.

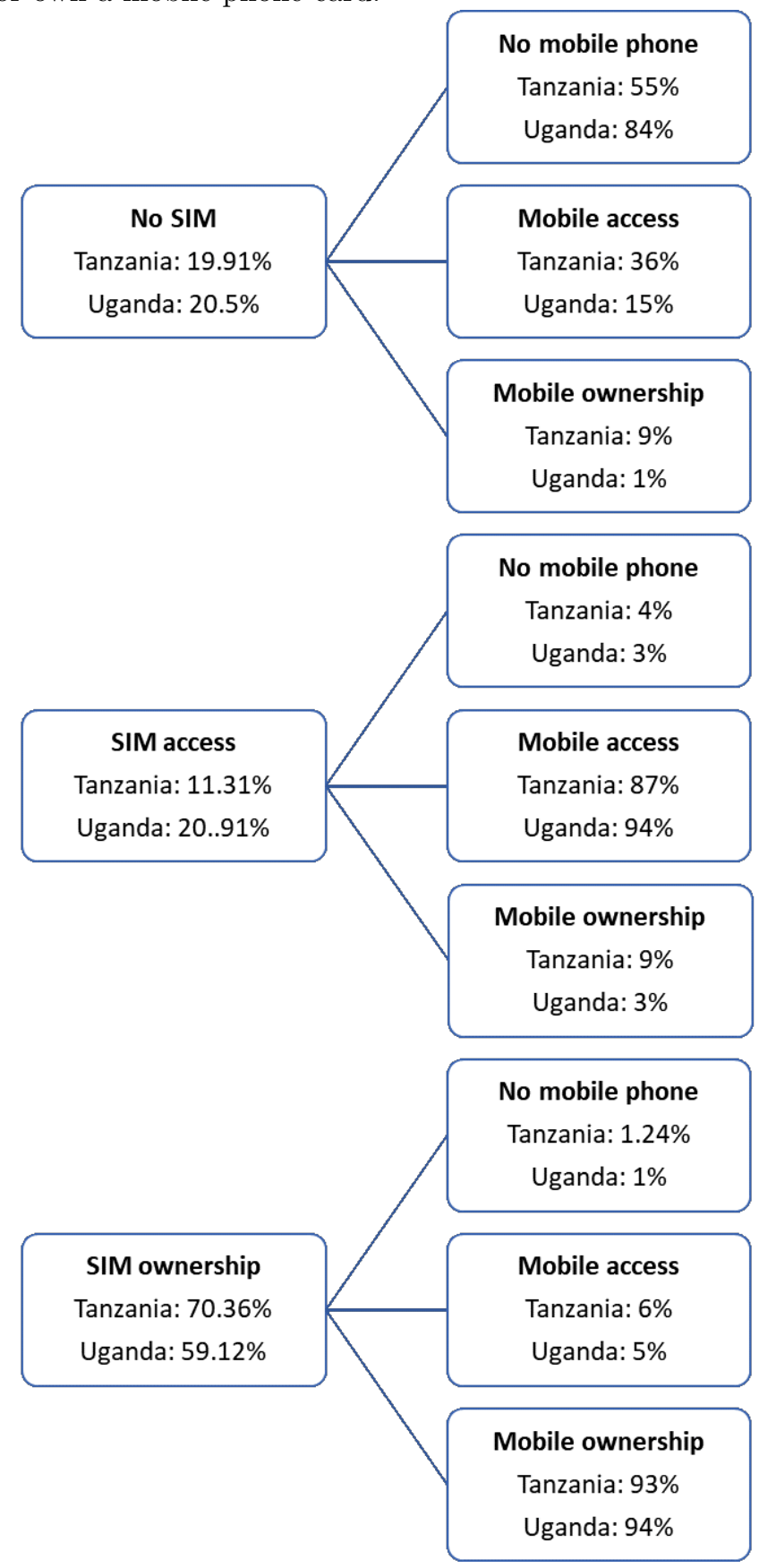

Own statistics: On the left part, from up to down. Proportion of individuals in our sample having no mobile phone, access to a mobile phone or owning a mobile phone which simultaneously have no SIM card, access to a SIM card or own a SIM card. On the right part, from up to down. Proportion of individuals in our sample having no SIM card, access to a SIM card or own a SIM card, which simultaneously have no mobile phone, access to a mobile phone or owning a mobile phone . 
Table 8: Evolution of Mobile Internet Use over 2013 and 2016 in urban and rural areas in our sample

\begin{tabular}{|l|ccc|}
\hline Year & Urban & Rural & Overall \\
\hline 2013 & 0.403 & 0.233 & 0.304 \\
2014 & 0.539 & 0.458 & 0.489 \\
2015 & 0.505 & 0.419 & 0.459 \\
2016 & 0.394 & 0.481 & 0.456 \\
\hline All year & 0.465 & 0.404 & 0.427 \\
\hline
\end{tabular}


Table 9a: Determinants of mobile broadband adoption whole sample between 2014 -2017: part 1

\begin{tabular}{|c|c|c|c|c|c|}
\hline dep var: Mobile broadband use & SSA & Nigeria & Kenya & Tanzania & Uganda \\
\hline Mobile ownership & $\begin{array}{c}1.371^{* * *} \\
(0.166)\end{array}$ & $\begin{array}{c}1.312^{* * *} \\
(0.367)\end{array}$ & $\begin{array}{c}0.903^{* * *} \\
(0.178)\end{array}$ & $\begin{array}{c}2.373^{* * *} \\
(0.266)\end{array}$ & $\begin{array}{c}1.259^{* * *} \\
(0.308)\end{array}$ \\
\hline SIM card access & $\begin{array}{c}2.783^{* * *} \\
(0.212)\end{array}$ & $\begin{array}{c}3.110^{* * *} \\
(0.311)\end{array}$ & $\begin{array}{c}2.989^{* * *} \\
(0.323)\end{array}$ & $\begin{array}{c}1.143^{* * *} \\
(0.275)\end{array}$ & $\begin{array}{c}4.221^{* * *} \\
(0.610)\end{array}$ \\
\hline SIM card ownership & $\begin{array}{c}2.665^{* * *} \\
(0.234)\end{array}$ & $\begin{array}{c}2.943^{* * *} \\
(0.436)\end{array}$ & $\begin{array}{c}3.370^{* * *} \\
(0.339)\end{array}$ & $\begin{array}{c}0.655^{* *} \\
(0.302)\end{array}$ & $\begin{array}{c}4.220^{* * *} \\
(0.654)\end{array}$ \\
\hline Social media & $\begin{array}{c}4.292^{* * *} \\
(0.093)\end{array}$ & $\begin{array}{c}4.420^{* * *} \\
(0.098)\end{array}$ & $\begin{array}{c}4.117^{* * *} \\
(0.123)\end{array}$ & $\begin{array}{c}3.989^{* * *} \\
(0.146)\end{array}$ & $\begin{array}{c}4.393^{* * *} \\
(0.174)\end{array}$ \\
\hline Mobile money: never used & & & & & \\
\hline Less than 1 month & $\begin{array}{c}0.880^{* * *} \\
(0.195)\end{array}$ & $\begin{array}{c}0.758 \\
(0.627)\end{array}$ & $\begin{array}{l}0.705^{*} \\
(0.368)\end{array}$ & $\begin{array}{c}1.102^{* * * *} \\
(0.288)\end{array}$ & $\begin{array}{c}-0.022 \\
(0.443)\end{array}$ \\
\hline Between 1 and 6 months & $\begin{array}{c}0.647^{* * *} \\
(0.139)\end{array}$ & $\begin{array}{l}0.992^{*} \\
(0.534)\end{array}$ & $\begin{array}{c}0.289 \\
(0.256)\end{array}$ & $\begin{array}{c}0.891^{* * * *} \\
(0.176)\end{array}$ & $\begin{array}{c}0.192 \\
(0.288)\end{array}$ \\
\hline Between 6 months and 1 year & $\begin{array}{c}0.629^{* * *} \\
(0.122)\end{array}$ & $\begin{array}{l}0.649^{*} \\
(0.392)\end{array}$ & $\begin{array}{c}0.315 \\
(0.237)\end{array}$ & $\begin{array}{c}0.791^{* * * *} \\
(0.202)\end{array}$ & $\begin{array}{l}0.367^{*} \\
(0.217)\end{array}$ \\
\hline More than 1 year & $\begin{array}{c}0.812^{* * *} \\
(0.096)\end{array}$ & $\begin{array}{c}1.747^{* * *} \\
(0.544)\end{array}$ & $\begin{array}{c}0.554^{* * *} \\
(0.181)\end{array}$ & $\begin{array}{c}0.927^{* * *} \\
(0.139)\end{array}$ & $\begin{array}{c}0.464^{* * *} \\
(0.167)\end{array}$ \\
\hline Bank account & $\begin{array}{c}0.443^{* * *} \\
(0.068)\end{array}$ & $\begin{array}{c}0.423^{* * *} \\
(0.090)\end{array}$ & $\begin{array}{c}0.481^{* * *} \\
(0.082)\end{array}$ & $\begin{array}{c}0.331^{* * *} \\
(0.120)\end{array}$ & $\begin{array}{c}0.682^{* * *} \\
(0.136)\end{array}$ \\
\hline Wealth (PPI index) & $\begin{array}{c}0.012^{* * *} \\
(0.002)\end{array}$ & $\begin{array}{c}0.011^{* * *} \\
(0.003)\end{array}$ & $\begin{array}{c}0.020^{* * *} \\
(0.003)\end{array}$ & $\begin{array}{c}0.009^{* * * *} \\
(0.003)\end{array}$ & $\begin{array}{c}0.028^{* * *} \\
(0.005)\end{array}$ \\
\hline Urban & $\begin{array}{c}0.254^{* * *} \\
(0.069)\end{array}$ & $\begin{array}{c}0.361^{* * *} \\
(0.091)\end{array}$ & $\begin{array}{c}0.038 \\
(0.092)\end{array}$ & $\begin{array}{c}0.055 \\
(0.104)\end{array}$ & $\begin{array}{c}0.218 \\
(0.138)\end{array}$ \\
\hline Gender $($ male $==1)$ & $\begin{array}{c}0.553^{* * *} \\
(0.047)\end{array}$ & $\begin{array}{c}0.482^{* * *} \\
(0.089)\end{array}$ & $\begin{array}{c}0.719^{* * *} \\
(0.072)\end{array}$ & $\begin{array}{c}0.459^{* * *} \\
(0.090)\end{array}$ & $\begin{array}{c}0.534^{* * *} \\
(0.117)\end{array}$ \\
\hline Constant & $\begin{array}{c}-8.066^{* * *} \\
(0.307) \\
\end{array}$ & $\begin{array}{c}-8.215^{* * *} \\
(0.375) \\
\end{array}$ & $\begin{array}{c}-8.663^{* * *} \\
(0.418) \\
\end{array}$ & $\begin{array}{c}-7.433^{* * *} \\
(0.415) \\
\end{array}$ & $\begin{array}{c}-10.577^{* * *} \\
(0.756) \\
\end{array}$ \\
\hline Observations & 57,364 & 24,348 & 11,796 & 9,925 & 11,295 \\
\hline Pseudo R-squared & 0.54 & 0.54 & 0.53 & 0.49 & 0.57 \\
\hline AIC & 29296.21 & 13947.89 & 6841.25 & 4501.83 & 3744.72 \\
\hline $\mathrm{BIC}$ & 30030.7 & 14231.39 & 7114.15 & 4941.20 & 4030.67 \\
\hline Log Likelihood & -14566.10 & -6938.94 & -3383.62 & -2189.91 & -1833.36 \\
\hline Region & YES & YES & YES & YES & YES \\
\hline Year Trend & YES & YES & YES & YES & YES \\
\hline
\end{tabular}

Robust standard errors in parentheses: ${ }^{* * *} p<0.01,{ }^{* *} p<0.05,{ }^{*} p<0.1$ 
Table 9b: Determinants of mobile broadband adoption whole sample between 2014-2017: part 2

\begin{tabular}{|c|c|c|c|c|c|}
\hline dep var: Mobile broadband use & SSA & Nigeria & Kenya & Tanzania & Uganda \\
\hline \multicolumn{6}{|l|}{ Age: $15-24$} \\
\hline $25-34$ & $\begin{array}{c}-0.444^{* * *} \\
(0.067)\end{array}$ & $\begin{array}{c}-0.311^{* * *} \\
(0.109)\end{array}$ & $\begin{array}{c}-0.460^{* * *} \\
(0.097)\end{array}$ & $\begin{array}{c}-0.402^{* * *} \\
(0.113)\end{array}$ & $\begin{array}{c}-0.858^{* * *} \\
(0.135)\end{array}$ \\
\hline $35-44$ & $\begin{array}{c}-0.863^{* * *} \\
(0.076)\end{array}$ & $\begin{array}{c}-0.642^{* * *} \\
(0.132)\end{array}$ & $\begin{array}{c}-1.074^{* * *} \\
(0.115)\end{array}$ & $\begin{array}{c}-0.824^{* * *} \\
(0.132)\end{array}$ & $\begin{array}{c}-1.329^{* * *} \\
(0.157)\end{array}$ \\
\hline $45-54$ & $\begin{array}{c}-1.199^{* * *} \\
(0.102)\end{array}$ & $\begin{array}{c}-0.963^{* * *} \\
(0.170)\end{array}$ & $\begin{array}{c}-1.585^{* * *} \\
(0.143)\end{array}$ & $\begin{array}{c}-1.274^{* * *} \\
(0.165)\end{array}$ & $\begin{array}{c}-1.342^{* * *} \\
(0.185)\end{array}$ \\
\hline Over 55 & $\begin{array}{c}-1.598^{* * *} \\
(0.110)\end{array}$ & $\begin{array}{c}-1.279^{* * *} \\
(0.155)\end{array}$ & $\begin{array}{c}-2.115^{* * *} \\
(0.152)\end{array}$ & $\begin{array}{c}-1.554^{* * *} \\
(0.186)\end{array}$ & $\begin{array}{c}-1.879^{* * *} \\
(0.231)\end{array}$ \\
\hline \multicolumn{6}{|l|}{ No formal education } \\
\hline Primary education & $\begin{array}{c}0.380^{* * *} \\
(0.119)\end{array}$ & $\begin{array}{c}0.410^{* *} \\
(0.202)\end{array}$ & $\begin{array}{c}0.334 \\
(0.239)\end{array}$ & $\begin{array}{c}0.530^{* *} \\
(0.240)\end{array}$ & $\begin{array}{l}-0.256 \\
(0.272)\end{array}$ \\
\hline Secondary education & $\begin{array}{c}1.069^{* * *} \\
(0.139)\end{array}$ & $\begin{array}{c}1.173^{* * *} \\
(0.159)\end{array}$ & $\begin{array}{c}0.916^{* * *} \\
(0.244)\end{array}$ & $\begin{array}{c}1.115^{* * *} \\
(0.249)\end{array}$ & $\begin{array}{l}0.489^{*} \\
(0.276)\end{array}$ \\
\hline Tertiary education & $\begin{array}{c}1.843^{* * *} \\
(0.129)\end{array}$ & $\begin{array}{c}1.800^{* * *} \\
(0.179)\end{array}$ & $\begin{array}{c}1.872^{* * *} \\
(0.264)\end{array}$ & $\begin{array}{c}1.877^{* * *} \\
(0.311)\end{array}$ & $\begin{array}{c}1.429 * * * \\
(0.324)\end{array}$ \\
\hline \multicolumn{6}{|l|}{ Intermediate professions } \\
\hline Farmers & $\begin{array}{c}-0.259^{* * *} \\
(0.100)\end{array}$ & $\begin{array}{c}-0.306^{*} \\
(0.167)\end{array}$ & $\begin{array}{c}-0.162 \\
(0.126)\end{array}$ & $\begin{array}{c}-0.330^{* *} \\
(0.151)\end{array}$ & $\begin{array}{c}0.132 \\
(0.193)\end{array}$ \\
\hline Craftsmen, self-employed & $\begin{array}{c}0.038 \\
(0.094)\end{array}$ & $\begin{array}{c}0.090 \\
(0.147)\end{array}$ & $\begin{array}{c}-0.058 \\
(0.135)\end{array}$ & $\begin{array}{c}0.105 \\
(0.166)\end{array}$ & $\begin{array}{c}0.018 \\
(0.208)\end{array}$ \\
\hline White collars & $\begin{array}{c}0.317^{* * *} \\
(0.096)\end{array}$ & $\begin{array}{l}0.292^{*} \\
(0.163)\end{array}$ & $\begin{array}{l}0.310^{*} \\
(0.182)\end{array}$ & $\begin{array}{c}0.715^{* * *} \\
(0.236)\end{array}$ & $\begin{array}{c}0.140 \\
(0.245)\end{array}$ \\
\hline Manual workers & $\begin{array}{c}0.079 \\
(0.081)\end{array}$ & $\begin{array}{c}0.082 \\
(0.144)\end{array}$ & $\begin{array}{c}0.004 \\
(0.138)\end{array}$ & $\begin{array}{c}0.241 \\
(0.164)\end{array}$ & $\begin{array}{c}0.072 \\
(0.206)\end{array}$ \\
\hline Military & $\begin{array}{l}0.389^{*} \\
(0.225)\end{array}$ & $\begin{array}{c}0.457 \\
(0.337)\end{array}$ & $\begin{array}{l}0.956^{*} \\
(0.569)\end{array}$ & $\begin{array}{c}0.429 \\
(0.403)\end{array}$ & $\begin{array}{l}-0.418 \\
(0.396)\end{array}$ \\
\hline Unemployed & $\begin{array}{l}-0.179^{*} \\
(0.101)\end{array}$ & $\begin{array}{l}-0.115 \\
(0.147)\end{array}$ & $\begin{array}{c}-0.226^{*} \\
(0.117)\end{array}$ & $\begin{array}{l}-0.019 \\
(0.220)\end{array}$ & $\begin{array}{l}-0.192 \\
(0.261)\end{array}$ \\
\hline Students & $\begin{array}{c}0.219^{* *} \\
(0.107)\end{array}$ & $\begin{array}{c}0.239 \\
(0.167)\end{array}$ & $\begin{array}{c}0.401^{* *} \\
(0.171)\end{array}$ & $\begin{array}{c}0.162 \\
(0.199)\end{array}$ & $\begin{array}{c}0.218 \\
(0.197)\end{array}$ \\
\hline Constant & $\begin{array}{c}-8.066^{* * *} \\
(0.307)\end{array}$ & $\begin{array}{c}-8.215^{* * *} \\
(0.375)\end{array}$ & $\begin{array}{c}-8.663^{* * *} \\
(0.418)\end{array}$ & $\begin{array}{c}-7.433^{* * *} \\
(0.415)\end{array}$ & $\begin{array}{c}-10.577^{* * *} \\
(0.756)\end{array}$ \\
\hline Observations & 57,364 & 24,348 & 11,796 & 9,925 & 11,295 \\
\hline Pseudo R-squared & 0.54 & 0.54 & 0.53 & 0.49 & 0.57 \\
\hline $\mathrm{AIC}$ & 29296.21 & 13947.89 & 6841.25 & 4501.83 & 3744.72 \\
\hline $\mathrm{BIC}$ & 30030.7 & 14231.39 & 7114.15 & 4941.20 & 4030.67 \\
\hline Log Likelihood & -14566.10 & -6938.94 & -3383.62 & -2189.91 & -1833.36 \\
\hline Region & YES & YES & YES & YES & YES \\
\hline Year Trend & YES & YES & YES & YES & YES \\
\hline
\end{tabular}

Robust standard errors in parentheses : ${ }^{* * *} p<0.01,{ }^{* *} p<0.05,{ }^{*} p<0.1$ 
Table 10a: Determinants of mobile broadband adoption Non-mobile owners between 2014-2017: part 1

\begin{tabular}{|c|c|c|c|c|c|}
\hline dep var: Mobile broadband use & SSA & Nigeria & Kenya & Tanzania & Uganda \\
\hline SIM card access & $\begin{array}{c}2.399^{* * *} \\
(0.263)\end{array}$ & $\begin{array}{c}2.867^{* * *} \\
(0.365)\end{array}$ & $\begin{array}{c}2.762^{* * *} \\
(0.423)\end{array}$ & $\begin{array}{c}0.610 \\
(0.404)\end{array}$ & $\begin{array}{c}3.873^{* * *} \\
(0.828)\end{array}$ \\
\hline SIM card ownership & $\begin{array}{c}2.590^{* * *} \\
(0.273)\end{array}$ & $\begin{array}{c}2.677^{* * *} \\
(0.403)\end{array}$ & $\begin{array}{c}3.331^{* * *} \\
(0.435)\end{array}$ & $\begin{array}{c}0.522 \\
(0.378)\end{array}$ & $\begin{array}{c}4.003^{* * *} \\
(0.813)\end{array}$ \\
\hline Social media & $\begin{array}{c}2.543^{* * *} \\
(0.210)\end{array}$ & $\begin{array}{c}2.230^{* * *} \\
(0.308)\end{array}$ & $\begin{array}{c}3.218^{* * *} \\
(0.362)\end{array}$ & $\begin{array}{c}1.507^{* * *} \\
(0.385)\end{array}$ & $\begin{array}{c}3.680 * * * \\
(0.443)\end{array}$ \\
\hline Mobile money: never used & & & & & \\
\hline Less than 1 month & $\begin{array}{c}1.411^{* * *} \\
(0.386)\end{array}$ & & $\begin{array}{c}1.905^{* * *} \\
(0.569)\end{array}$ & $\begin{array}{c}2.501^{* * *} \\
(0.607)\end{array}$ & $\begin{array}{c}1.193 \\
(0.740)\end{array}$ \\
\hline Between 1 and 6 months & $\begin{array}{c}0.738^{* *} \\
(0.339)\end{array}$ & $\begin{array}{c}0.861 \\
(0.784)\end{array}$ & $\begin{array}{l}1.182^{* *} \\
(0.499)\end{array}$ & $\begin{array}{l}1.238^{* *} \\
(0.498)\end{array}$ & $\begin{array}{c}0.006 \\
(0.924)\end{array}$ \\
\hline Between 6 months and 1 year & $\begin{array}{c}0.900^{* * *} \\
(0.278)\end{array}$ & & $\begin{array}{l}1.141^{* *} \\
(0.444)\end{array}$ & $\begin{array}{c}1.542^{* * *} \\
(0.481)\end{array}$ & $\begin{array}{c}0.543 \\
(0.484)\end{array}$ \\
\hline More than 1 year & $\begin{array}{c}1.145^{* * *} \\
(0.161)\end{array}$ & $\begin{array}{c}-0.739 \\
(1.422)\end{array}$ & $\begin{array}{c}1.470^{* * *} \\
(0.271)\end{array}$ & $\begin{array}{c}1.689^{* * *} \\
(0.323)\end{array}$ & $\begin{array}{c}0.689^{* *} \\
(0.325)\end{array}$ \\
\hline Bank account & $\begin{array}{c}0.650^{* *} \\
(0.312)\end{array}$ & $\begin{array}{c}0.672 \\
(0.470)\end{array}$ & $\begin{array}{c}0.491 \\
(0.424)\end{array}$ & $\begin{array}{l}-0.398 \\
(0.712)\end{array}$ & $\begin{array}{c}1.763^{* * *} \\
(0.618)\end{array}$ \\
\hline Wealth (PPI index) & $\begin{array}{c}0.012^{* * *} \\
(0.004)\end{array}$ & $\begin{array}{c}0.018^{* *} \\
(0.008)\end{array}$ & $\begin{array}{c}0.011 \\
(0.007)\end{array}$ & $\begin{array}{c}0.005 \\
(0.008)\end{array}$ & $\begin{array}{c}0.030^{* *} \\
(0.013)\end{array}$ \\
\hline Urban & $\begin{array}{c}0.347^{* *} \\
(0.163)\end{array}$ & $\begin{array}{c}0.538^{* *} \\
(0.251)\end{array}$ & $\begin{array}{c}0.230 \\
(0.304)\end{array}$ & $\begin{array}{l}-0.022 \\
(0.362)\end{array}$ & $\begin{array}{c}0.049 \\
(0.334)\end{array}$ \\
\hline Gender $($ male $==1)$ & $\begin{array}{c}0.601^{* * *} \\
(0.135)\end{array}$ & $\begin{array}{c}0.748^{* * *} \\
(0.258)\end{array}$ & $\begin{array}{c}0.571^{* * *} \\
(0.211)\end{array}$ & $\begin{array}{c}0.253 \\
(0.286)\end{array}$ & $\begin{array}{c}0.690^{* *} \\
(0.269)\end{array}$ \\
\hline Constant & $\begin{array}{c}-7.397^{* * * *} \\
(0.578)\end{array}$ & $\begin{array}{c}-10.015^{* * *} \\
(0.962)\end{array}$ & $\begin{array}{c}-7.965^{* * *} \\
(1.149)\end{array}$ & $\begin{array}{c}-5.116^{* * *} \\
(1.037)\end{array}$ & $\begin{array}{c}-11.895^{* * *} \\
(1.656)\end{array}$ \\
\hline Observations & 16,342 & 6,091 & 2,567 & 2,570 & 5,079 \\
\hline Pseudo R-squared & 0.34 & 0.34 & 0.38 & 0.27 & 0.39 \\
\hline $\mathrm{AIC}$ & -2021.35 & 1458.52 & 1197.75 & 676.5 & 736.9 \\
\hline $\mathrm{BIC}$ & 4190.71 & 1666.67 & 1402.52 & 969.1 & 978.61 \\
\hline Log Likelihood & 4760.62 & -698.26 & -563.87 & -288.26 & -331.45 \\
\hline Region & YES & YES & YES & YES & YES \\
\hline Year Trend & YES & YES & YES & YES & YES \\
\hline
\end{tabular}

Robust standard errors in parentheses : ${ }^{* * *} p<0.01,{ }^{* *} p<0.05,{ }^{*} p<0.1$ 
Table 10b: Determinants of mobile broadband adoption Non-mobile owners between 2014-2017: part 2

\begin{tabular}{|c|c|c|c|c|c|}
\hline dep var: Mobile broadband use & $\mathrm{SSA}$ & Nigeria & Kenya & Tanzania & Uganda \\
\hline Age: $15-24$ & & & & & \\
\hline $25-34$ & $\begin{array}{c}-0.452^{* * *} \\
(0.143)\end{array}$ & $\begin{array}{l}-0.507^{*} \\
(0.288)\end{array}$ & $\begin{array}{l}-0.142 \\
(0.281)\end{array}$ & $\begin{array}{l}-0.272 \\
(0.297)\end{array}$ & $\begin{array}{c}-0.992^{* * * *} \\
(0.320)\end{array}$ \\
\hline $35-44$ & $\begin{array}{c}-0.596^{* * *} \\
(0.217)\end{array}$ & $\begin{array}{l}-0.172 \\
(0.380)\end{array}$ & $\begin{array}{c}-0.875^{* *} \\
(0.391)\end{array}$ & $\begin{array}{l}-0.328 \\
(0.410)\end{array}$ & $\begin{array}{c}-1.051^{* *} \\
(0.466)\end{array}$ \\
\hline $45-54$ & $\begin{array}{c}-0.573^{* *} \\
(0.251)\end{array}$ & $\begin{array}{l}-0.139 \\
(0.420)\end{array}$ & $\begin{array}{l}-0.553 \\
(0.482)\end{array}$ & $\begin{array}{l}-0.510 \\
(0.448)\end{array}$ & $\begin{array}{c}-1.226^{* *} \\
(0.587)\end{array}$ \\
\hline $\begin{array}{l}\text { Over } 55 \\
\text { No formal education }\end{array}$ & $\begin{array}{c}-1.257^{* * *} \\
(0.277)\end{array}$ & $\begin{array}{c}-1.478^{* * *} \\
(0.513)\end{array}$ & $\begin{array}{l}-0.469 \\
(0.409)\end{array}$ & $\begin{array}{l}-0.922 \\
(0.668)\end{array}$ & $\begin{array}{c}-2.371^{* * * *} \\
(0.599)\end{array}$ \\
\hline Primary education & $\begin{array}{c}0.574^{* * *} \\
(0.203)\end{array}$ & $\begin{array}{c}0.461 \\
(0.354)\end{array}$ & $\begin{array}{c}0.028 \\
(0.356)\end{array}$ & $\begin{array}{l}0.903^{*} \\
(0.547)\end{array}$ & $\begin{array}{l}-0.100 \\
(0.420)\end{array}$ \\
\hline Secondary education & $\begin{array}{c}1.148^{* * *} \\
(0.232)\end{array}$ & $\begin{array}{c}1.586^{* * *} \\
(0.291)\end{array}$ & $\begin{array}{c}0.285 \\
(0.396)\end{array}$ & $\begin{array}{c}1.696^{* * *} \\
(0.587)\end{array}$ & $\begin{array}{c}0.319 \\
(0.498)\end{array}$ \\
\hline Tertiary education & $\begin{array}{c}1.183^{* * *} \\
(0.378)\end{array}$ & $\begin{array}{l}1.262^{* *} \\
(0.583)\end{array}$ & $\begin{array}{c}0.380 \\
(0.605)\end{array}$ & $\begin{array}{c}2.141 \\
(1.600)\end{array}$ & $\begin{array}{l}1.818^{*} \\
(1.080)\end{array}$ \\
\hline Intermediate professions & & & & & \\
\hline Farmers & $\begin{array}{c}0.332 \\
(0.271)\end{array}$ & $\begin{array}{c}0.629 \\
(0.500)\end{array}$ & $\begin{array}{c}0.401 \\
(0.637)\end{array}$ & $\begin{array}{l}-0.775 \\
(0.490)\end{array}$ & $\begin{array}{l}1.971^{*} \\
(1.036)\end{array}$ \\
\hline Craftsmen, self-employed & $\begin{array}{c}0.647^{* *} \\
(0.299)\end{array}$ & $\begin{array}{c}1.017^{* *} \\
(0.487)\end{array}$ & $\begin{array}{c}0.185 \\
(0.806)\end{array}$ & $\begin{array}{c}0.159 \\
(0.532)\end{array}$ & $\begin{array}{l}2.029^{*} \\
(1.139)\end{array}$ \\
\hline White collars & $\begin{array}{l}-0.009 \\
(0.511)\end{array}$ & $\begin{array}{c}0.619 \\
(0.700)\end{array}$ & & & $\begin{array}{c}0.353 \\
(1.523)\end{array}$ \\
\hline Manual workers & $\begin{array}{c}0.359 \\
(0.289)\end{array}$ & $\begin{array}{c}0.672 \\
(0.495)\end{array}$ & $\begin{array}{c}0.700 \\
(0.662)\end{array}$ & $\begin{array}{l}-0.428 \\
(0.538)\end{array}$ & $\begin{array}{c}1.331 \\
(1.116)\end{array}$ \\
\hline Military & $\begin{array}{c}0.269 \\
(1.390)\end{array}$ & & $\begin{array}{c}2.779 \\
(2.809)\end{array}$ & & \\
\hline Unemployed & $\begin{array}{c}0.416 \\
(0.265)\end{array}$ & $\begin{array}{l}1.188^{* *} \\
(0.504)\end{array}$ & $\begin{array}{c}0.170 \\
(0.606)\end{array}$ & $\begin{array}{l}-0.212 \\
(0.567)\end{array}$ & $\begin{array}{c}0.887 \\
(1.191)\end{array}$ \\
\hline Students & $\begin{array}{c}0.567^{* *} \\
(0.265)\end{array}$ & $\begin{array}{l}0.948^{*} \\
(0.497)\end{array}$ & $\begin{array}{l}1.172^{*} \\
(0.678)\end{array}$ & $\begin{array}{l}-0.618 \\
(0.631)\end{array}$ & $\begin{array}{l}1.959^{*} \\
(1.028)\end{array}$ \\
\hline Constant & $\begin{array}{c}-7.397^{* * * *} \\
(0.578)\end{array}$ & $\begin{array}{c}-10.015^{* * *} \\
(0.962)\end{array}$ & $\begin{array}{c}-7.965^{* * *} \\
(1.149)\end{array}$ & $\begin{array}{c}-5.116^{* * *} \\
(1.037)\end{array}$ & $\begin{array}{c}-11.895^{* * * *} \\
(1.656)\end{array}$ \\
\hline Observations & 16,342 & 6,091 & 2,567 & 2,570 & 5,079 \\
\hline Pseudo R-squared & 0.34 & 0.34 & 0.38 & 0.27 & 0.39 \\
\hline $\mathrm{AIC}$ & -2021.35 & 1458.52 & 1197.75 & 676.5 & 736.9 \\
\hline $\mathrm{BIC}$ & 4190.71 & 1666.67 & 1402.52 & 969.1 & 978.61 \\
\hline Log Likelihood & 4760.62 & -698.26 & -563.87 & -288.26 & -331.45 \\
\hline Region & YES & YES & YES & YES & YES \\
\hline Year Trend & YES & YES & YES & YES & YES \\
\hline
\end{tabular}

Robust standard errors in parentheses : ${ }^{* * *} p<0.01,{ }^{* *} p<0.05,{ }^{*} p<0.1$ 
Table 11a: Determinants of mobile broadband adoption Nigeria, Kenya, between 2013-2017: part 1

\begin{tabular}{|c|c|c|c|c|}
\hline dep var: Mobile broadband use & $\begin{array}{c}\text { Nigeria } \\
\text { Whole sample }\end{array}$ & $\begin{array}{c}\text { Kenya } \\
\text { Whole sample }\end{array}$ & $\begin{array}{c}\text { Nigeria } \\
\text { Non mobile owners }\end{array}$ & $\begin{array}{c}\text { Kenya } \\
\text { Non mobile owners }\end{array}$ \\
\hline Mobile ownership & $\begin{array}{c}1.180^{* * *} \\
(0.302)\end{array}$ & $\begin{array}{c}0.907^{* * *} \\
(0.177)\end{array}$ & & \\
\hline SIM card access & $\begin{array}{c}3.132^{* * *} \\
(0.300)\end{array}$ & $\begin{array}{c}3.013^{* * *} \\
(0.324)\end{array}$ & $\begin{array}{c}2.893^{* * *} \\
(0.348)\end{array}$ & $\begin{array}{c}2.812^{* * *} \\
(0.425)\end{array}$ \\
\hline SIM card ownership & $\begin{array}{c}3.096^{* * *} \\
(0.390)\end{array}$ & $\begin{array}{c}3.393^{* * *} \\
(0.340)\end{array}$ & $\begin{array}{c}2.824^{* * *} \\
(0.390)\end{array}$ & $\begin{array}{c}3.368^{* * *} \\
(0.442)\end{array}$ \\
\hline Social media & $\begin{array}{c}4.432^{* * *} \\
(0.100)\end{array}$ & $\begin{array}{c}4.117^{* * *} \\
(0.124)\end{array}$ & $\begin{array}{c}2.286^{* * *} \\
(0.301)\end{array}$ & $\begin{array}{c}3.251^{* * *} \\
(0.362)\end{array}$ \\
\hline Mobile money: never used & & & & \\
\hline Less than 1 month & $\begin{array}{c}0.805 \\
(0.646)\end{array}$ & $\begin{array}{l}0.704^{*} \\
(0.371)\end{array}$ & & $\begin{array}{c}1.948^{* * *} \\
(0.600)\end{array}$ \\
\hline Between 1 and 6 months & $\begin{array}{l}1.005^{* *} \\
(0.509)\end{array}$ & $\begin{array}{c}0.286 \\
(0.255)\end{array}$ & $\begin{array}{c}0.856 \\
(0.766)\end{array}$ & $\begin{array}{l}1.185^{* *} \\
(0.497)\end{array}$ \\
\hline Between 6 months and 1 year & $\begin{array}{c}0.563 \\
(0.398)\end{array}$ & $\begin{array}{c}0.299 \\
(0.237)\end{array}$ & & $\begin{array}{c}1.161^{* * *} \\
(0.435)\end{array}$ \\
\hline More than 1 year & $\begin{array}{c}1.747^{* * *} \\
(0.563)\end{array}$ & $\begin{array}{c}0.552^{* * *} \\
(0.179)\end{array}$ & $\begin{array}{l}-0.370 \\
(1.159)\end{array}$ & $\begin{array}{c}1.497^{* * *} \\
(0.265)\end{array}$ \\
\hline Bank account & $\begin{array}{c}0.540^{* * *} \\
(0.068)\end{array}$ & $\begin{array}{c}0.454^{* * * *} \\
(0.082)\end{array}$ & $\begin{array}{c}0.654 \\
(0.435)\end{array}$ & $\begin{array}{c}0.468 \\
(0.426)\end{array}$ \\
\hline Wealth (PPI index) & $\begin{array}{c}0.014^{* * *} \\
(0.004)\end{array}$ & $\begin{array}{c}0.027^{* * *} \\
(0.004)\end{array}$ & $\begin{array}{l}0.021^{* *} \\
(0.010)\end{array}$ & $\begin{array}{l}0.015^{*} \\
(0.009)\end{array}$ \\
\hline Urban & $\begin{array}{c}0.383^{* * *} \\
(0.066)\end{array}$ & $\begin{array}{c}0.034 \\
(0.091)\end{array}$ & $\begin{array}{c}0.665^{* * *} \\
(0.227)\end{array}$ & $\begin{array}{c}0.198 \\
(0.293)\end{array}$ \\
\hline Gender $($ male $==1)$ & $\begin{array}{c}0.494^{* * *} \\
(0.068)\end{array}$ & $\begin{array}{c}0.744^{* * *} \\
(0.074)\end{array}$ & $\begin{array}{c}0.787^{* * *} \\
(0.243)\end{array}$ & $\begin{array}{c}0.564^{* * *} \\
(0.208)\end{array}$ \\
\hline No formal education & & & & \\
\hline Primary education & $\begin{array}{c}0.213 \\
(0.187)\end{array}$ & $\begin{array}{c}0.278 \\
(0.249)\end{array}$ & $\begin{array}{c}0.333 \\
(0.360)\end{array}$ & $\begin{array}{c}0.071 \\
(0.365)\end{array}$ \\
\hline Secondary education & $\begin{array}{c}0.944^{* * *} \\
(0.146)\end{array}$ & $\begin{array}{c}0.828^{* * *} \\
(0.257)\end{array}$ & $\begin{array}{c}1.482^{* * *} \\
(0.281)\end{array}$ & $\begin{array}{c}0.317 \\
(0.405)\end{array}$ \\
\hline Tertiary education & $\begin{array}{c}1.714^{* * *} \\
(0.157)\end{array}$ & $\begin{array}{c}1.779^{* * *} \\
(0.277)\end{array}$ & $\begin{array}{c}1.421^{* * *} \\
(0.522)\end{array}$ & $\begin{array}{c}0.413 \\
(0.604)\end{array}$ \\
\hline Constant & $\begin{array}{c}-11.787^{* * *} \\
(0.401)\end{array}$ & $\begin{array}{c}-28.631^{* * *} \\
(0.944)\end{array}$ & $\begin{array}{c}-11.870^{* * *} \\
(1.063)\end{array}$ & $\begin{array}{c}-25.191^{* * *} \\
(1.294)\end{array}$ \\
\hline Observations & 30,350 & 12,406 & 6,567 & 2,981 \\
\hline Pseudo R-squared & 0.48 & 0.55 & 0.35 & 0.41 \\
\hline $\mathrm{AIC}$ & 19291.93 & 6829.69 & 1851.44 & 1203.39 \\
\hline $\mathrm{BIC}$ & 19641.4 & 7126.73 & 1593.42 & 1449.39 \\
\hline Log Likelihood & -9603.96 & -3374.84 & -758.71 & -560.69 \\
\hline Region & YES & YES & YES & YES \\
\hline Year Trend & YES & YES & YES & YES \\
\hline
\end{tabular}

Robust standard errors in parentheses : ${ }^{* *} p<0.01,{ }^{* *} p<0.05,{ }^{*} p<0.1$ 
Table 11b: Determinants of mobile broadband adoption Nigeria, Kenya, between 2013-2017: part 2

\begin{tabular}{|c|c|c|c|c|}
\hline dep var: Mobile broadband use & $\begin{array}{c}\text { Nigeria } \\
\text { Whole sample }\end{array}$ & $\begin{array}{c}\text { Kenya } \\
\text { Whole sample }\end{array}$ & $\begin{array}{c}\text { Nigeria } \\
\text { Non mobile owners }\end{array}$ & $\begin{array}{c}\text { Kenya } \\
\text { Non mobile owners }\end{array}$ \\
\hline \multicolumn{5}{|l|}{ Age: 15-24 } \\
\hline $25-34$ & $\begin{array}{c}-0.391^{* * *} \\
(0.078)\end{array}$ & $\begin{array}{c}-0.481^{* * *} \\
(0.097)\end{array}$ & $\begin{array}{r}-0.530^{*} \\
(0.276)\end{array}$ & $\begin{array}{l}-0.111 \\
(0.286)\end{array}$ \\
\hline $35-44$ & $\begin{array}{c}-0.835^{* * *} \\
(0.098)\end{array}$ & $\begin{array}{c}-1.135^{* * *} \\
(0.116)\end{array}$ & $\begin{array}{l}-0.251 \\
(0.373)\end{array}$ & $\begin{array}{c}-0.860^{* *} \\
(0.392)\end{array}$ \\
\hline $45-54$ & $\begin{array}{c}-1.132^{* * *} \\
(0.132)\end{array}$ & $\begin{array}{c}-1.644^{* * *} \\
(0.145)\end{array}$ & $\begin{array}{l}-0.092 \\
(0.402)\end{array}$ & $\begin{array}{l}-0.540 \\
(0.489)\end{array}$ \\
\hline Over 55 & $\begin{array}{c}-1.438^{* * *} \\
(0.130)\end{array}$ & $\begin{array}{c}-2.146^{* * *} \\
(0.153)\end{array}$ & $\begin{array}{c}-1.499^{* * *} \\
(0.488)\end{array}$ & $\begin{array}{l}-0.452 \\
(0.416)\end{array}$ \\
\hline \multicolumn{5}{|l|}{ Intermediate professions } \\
\hline Farmers & $\begin{array}{c}-0.295^{* *} \\
(0.133)\end{array}$ & $\begin{array}{l}-0.164 \\
(0.126)\end{array}$ & $\begin{array}{c}0.706 \\
(0.505)\end{array}$ & $\begin{array}{c}0.439 \\
(0.659)\end{array}$ \\
\hline Craftsmen, self-employed & $\begin{array}{c}0.042 \\
(0.107)\end{array}$ & $\begin{array}{l}-0.062 \\
(0.136)\end{array}$ & $\begin{array}{l}1.097^{* *} \\
(0.486)\end{array}$ & $\begin{array}{c}0.238 \\
(0.833)\end{array}$ \\
\hline White collars & $\begin{array}{c}0.192 \\
(0.125)\end{array}$ & $\begin{array}{c}0.279 \\
(0.182)\end{array}$ & $\begin{array}{c}0.449 \\
(0.714)\end{array}$ & \\
\hline Manual workers & $\begin{array}{c}0.072 \\
(0.103)\end{array}$ & $\begin{array}{c}0.007 \\
(0.139)\end{array}$ & $\begin{array}{c}0.728 \\
(0.483)\end{array}$ & $\begin{array}{c}0.820 \\
(0.688)\end{array}$ \\
\hline Military & $\begin{array}{c}0.460 \\
(0.283)\end{array}$ & $\begin{array}{l}0.916^{*} \\
(0.557)\end{array}$ & & $\begin{array}{c}2.816 \\
(2.802)\end{array}$ \\
\hline Unemployed & $\begin{array}{l}-0.084 \\
(0.110)\end{array}$ & $\begin{array}{c}-0.234^{* *} \\
(0.117)\end{array}$ & $\begin{array}{l}1.255^{* *} \\
(0.490)\end{array}$ & $\begin{array}{c}0.250 \\
(0.626)\end{array}$ \\
\hline Students & $\begin{array}{c}0.362^{* * *} \\
(0.117)\end{array}$ & $\begin{array}{l}0.308^{*} \\
(0.170)\end{array}$ & $\begin{array}{l}0.959^{*} \\
(0.491)\end{array}$ & $\begin{array}{l}1.181^{*} \\
(0.708)\end{array}$ \\
\hline Number of household members: 1 & & & & \\
\hline 2 household members & $\begin{array}{l}0.210^{* *} \\
(0.086)\end{array}$ & $\begin{array}{c}0.052 \\
(0.102)\end{array}$ & $\begin{array}{c}0.664^{* *} \\
(0.327)\end{array}$ & $\begin{array}{c}0.148 \\
(0.313)\end{array}$ \\
\hline 3 household members & $\begin{array}{l}0.226^{* *} \\
(0.099)\end{array}$ & $\begin{array}{c}0.178 \\
(0.113)\end{array}$ & $\begin{array}{c}0.369 \\
(0.470)\end{array}$ & $\begin{array}{l}-0.174 \\
(0.322)\end{array}$ \\
\hline 4 household members & $\begin{array}{c}0.367 * * * \\
(0.104)\end{array}$ & $\begin{array}{c}0.214 \\
(0.134)\end{array}$ & $\begin{array}{c}1.198^{* * *} \\
(0.339)\end{array}$ & $\begin{array}{l}-0.178 \\
(0.407)\end{array}$ \\
\hline 5 household members & $\begin{array}{c}0.291^{* *} \\
(0.119)\end{array}$ & $\begin{array}{c}0.259 \\
(0.159)\end{array}$ & $\begin{array}{c}0.778^{*} \\
(0.408)\end{array}$ & $\begin{array}{c}-0.196 \\
(0.415)\end{array}$ \\
\hline 6 or more household members & $\begin{array}{c}0.478^{* * *} \\
(0.163)\end{array}$ & $\begin{array}{c}0.573^{* * *} \\
(0.174)\end{array}$ & $\begin{array}{c}0.772^{*} \\
(0.414)\end{array}$ & $\begin{array}{c}0.365 \\
(0.392)\end{array}$ \\
\hline Television & $\begin{array}{c}-0.447^{* * *} \\
(0.085)\end{array}$ & & $\begin{array}{c}-0.317 \\
(0.198)\end{array}$ & \\
\hline Constant & $\begin{array}{c}-11.787^{* * *} \\
(0.401)\end{array}$ & $\begin{array}{c}-28.631^{* * *} \\
(0.944)\end{array}$ & $\begin{array}{c}-11.870^{* * *} \\
(1.063)\end{array}$ & $\begin{array}{c}-25.191^{* * *} \\
(1.294)\end{array}$ \\
\hline Observations & 30,350 & 12,406 & 6,567 & 2,981 \\
\hline Pseudo R-squared & 0.48 & 0.55 & 0.35 & 0.41 \\
\hline $\mathrm{AIC}$ & 19291.93 & 6829.69 & 1851.44 & 1203.39 \\
\hline $\mathrm{BIC}$ & 19641.4 & 7126.73 & 1593.42 & 1449.39 \\
\hline Log Likelihood & -9603.96 & -3374.84 & -758.71 & -560.69 \\
\hline Region & YES & YES & YES & YES \\
\hline Year Trend & YES & YES & YES & YES \\
\hline
\end{tabular}

Robust standard errors in parentheses : ${ }^{* * *} p<0.01,{ }^{* *} p<0.05,{ }^{*} p<0.1$ 